\title{
DOES THE CONSTITUTION PREVENT THE DISCHARGE OF CIVIL SERVIGE EMPLOYEES?
}

\author{
Gerald E. Frug $\dagger$
}

He'll sit here . . . and he'll say "Do this! Do that!" And nothing will happen. Poor Ike-it won't be a bit like the Army. He'll find it very frustrating.

Harry S. Truman*

\section{TABLE OF CONTENTS}

I. INTRODUCTION

II. The Power to Remove Government Employees:

The Historical Background

A. The First Hundred Years ..................................... 947

B. Civil Service Reform........................................... 954

C. The Role of the Courts .......................................... 961

1. Prior to Bailey v. Richardson .......................... 961

2. From Bailey $v$. Richardson to Board of Regents $v$. Roth .............................................. 970

III. RoTH, SINDERMANN, AND ARNETT ............................ 977

A. What the Cases Hold .......................................... 977

B. The Requirements of Procedural Due Process in a Discharge for Inadequate Job Performance ............... 989

1. The Nature of the Governmental Interest ... 990

2. The Interest of the Affected Employee....... 996

3. Fairness in Employee Discharges ................. 1002

4. Requirements for the Protection of "Liberty"

IV. CONCLUSION 1111

$\dagger$ Associate Professor of Law, University of Pennsylvania. A.B. 1960, University of California at Berkeley; LL.B. 1963, Harvard University. Mr. Frug is a former Health Services Administrator of the City of New York.

* Quoted in R. Neustadt, Presidential Power: The Politics of Leadership 9 (1960) (emphasis in original). 


\section{INTRODUCTION}

The dramatic expansion of the size and scope of government in the last twenty years ${ }^{1}$ has made government the pivotal force in the development of American society. The quality of that society is thus significantly influenced by the quality of those who decide and implement governmental policies. Yet the increase in the importance of government has been accompanied by a decrease in the level of public confidence in the government work force. The public reaction evidences doubt whether the government, as presently constituted, has the ability to carry out its expanded responsibilities. ${ }^{2}$ Government personnel seem not only ineffective but also unresponsive either to the public or to elected officials; the bureaucracy has developed a life of its own. Efforts abound to make the government more accountable to the

1 The percentage of the nation's work force attributable to government employment has almost doubled in the last twenty years, to a current total of about $15.7 \%$. Compare Economic Report of the President 57 (1975) with Special Analyses, Budget OF THE UNited States Government, Fiscal Year 1976, at 136 (1975). The percentage of the nation's gross national product attributable to civilian government expenditures has also doubled in the same period and now exceeds $25 \%$. U.S. Advisory Comm'N oN INTERGOVernmental Relations, TRENDS in FisCal Federalism 1954-1974, at 1 (1975). As a result, the tax burden of the average family has doubled during the same period. Id. 3. These increases are attributable in part to a significant shift in federal budgetary emphasis from defense and foreign affairs to income support and social programs, increasing these domestic expenditures from $27.3 \%$ to $49 \%$ of the federal budget since 1960. B. Blechman, E. Gramlich \& R. Hartman, Setring National Priorities: The 1976 Budget 4-8 (1975) [hereinafter cited as BlechmaN]. The expansion of the scope of state and local government activities has exceeded even that of the federal government, in part because of a federal policy of implementing its programs through grantsin-aid to states and localities, causing these grants to grow nine-fold in dollar amount since 1960 (amounting to a $6 \%$ increase within overall federal outlays), and in part because of locally generated pressures to expand governmental activity to such areas as drug addiction, pollution control, and consumer protection. Id. 8; C. Schultze, E. Fried, A. Rivlin \& N. Teeters, Serting National Priorities: The 1973 Budget 292-302 (1972) [hereinafter cited as Schultze]. See generally The Budget of THE United States Government, Fiscal Year 1976, at 8-10 (1975) (Budget Message of the President); Special Analysis O, Federal Aid to State and Local Government, in SPECIAL. Analyses, Budget of the United States Government, Fiscal Year 1976, at 235-51 (1975); U.S. ADvisory COMM'N ON INTERgoverNMENTAL Relations, supra.

2 The widespread cynicism about government, see, e.g., N.Y. Times, Apr. 14, 1974, $\S 1$ at 43 , col. 7 (voter cynicism about the conduct of elected officials impels state campaign spending regulations and ethics law reform), is reflected in the increasing number of politicians questioning the value and wisdom of government's attempts to solve social problems. See, e.g., Reeves, "How Does the Governor of California Differ from a Shoemaker?," N.Y. Times, Aug. 24, 1975, § 6 pt. 1 (Magazine), at 8. One approach to the expansion of government is to question how it can be justified. See R. Nozick, ANarchy, State and Utopia (1974). In this Article, I assume the existence of an important role for government in our society and seek ways to improve the ability of the government to perform the responsibilities given it. 
public through open meeting laws, ${ }^{3}$ increased access to public records, ${ }^{4}$ citizen participation in the formulation of policy, ${ }^{5}$ decentralization of government functions, ${ }^{6}$ and requirements that government articulate the rationale behind its policies prior to taking important actions. ${ }^{7}$ But no amount of citizen involvement in policymaking can compensate for an inadequate government work force. Government's effectiveness and responsiveness depend on the quality and management of governmental personnel. That personnel administration plays an essential governmental role is underscored by the fact that employee costs account for most government expenditures at the state and local level $^{8}$ and for most controllable expenditures at the federal level. ${ }^{9}$ Even an attempt to improve the process of government simply to eliminate budgetary deficits ${ }^{10}$ must concentrate on personnel policy.

Government's ability to improve personnel policy-whether for reasons of governmental effectiveness or efficiencyis now limited both by the civil service system and by unionization of government employees. The growing impact of public employee unions on government operations, both because of the unions' contractual rights and their increasing political power, has been widely noted. ${ }^{11}$ The more pervasive restrictions

${ }^{3}$ See, e.g., CAL. Gov'T Code $\S \S 54950-61$ (West Supp. 1975). See generally Wickham, Let the Sun Shine In! Open-Meeting Legislation Can Be Our Key to Closed Doors in State and Local Government, 68 Nw. U.L. Rev. 480 (1973); Note, Open Meeting Statutes: The Press Fights for the "Right to Know," 75 Harv. L. Rev. 1199 (1962); Comment, Pennsylvania's "Sunshine Law": Problems of Construction and Enforcement, 124 U. PA. L. REv. 536 (1975).

4 See, e.g., Freedom of Information Act, 5 U.S.C. \$ 552 (1970), as amended, (Supp. IV, 1974). See generally Note, The Freedom of Information Act: A Seven-Year Assessment, 74 Colum. L. Rev. 895 (1974); Note, The Freedom of Information Act and the Exemption for Intra-Agency Memoranda, 86 HaRv. L. Rev. 1047 (1973); Comment, In Camera Inspections Under the Freedom of Information Act, 41 U. CHI. L. REv. 557 (1974); Comment, National Security and the Public's Right to Know: A New Role for the Courts Under the Freedom of Information Act, 123 U. PA. L. REv. 1438 (1975).

${ }^{5}$ See, e.g., Economic Opportunity Act of $1964 \S 201,42$ U.S.C. $\S 2781$ (a) (1970); New York City Health and Hospitals Corporation Act, N.Y. Unconsol. LAws $\S$ 7384(11) (McKinney Supp. 1975).

${ }^{6}$ See, e.g., N.Y. Educ. Law $§ 2564$ (McKinney 1970).

${ }^{7}$ See, e.g., National Environmental Policy Act of $1969 \S$ 102(2)(c), 42 U.S.C. $\S$ 4332(2)(C) (1970).

${ }^{8}$ U.S. Advisory Comm'n on Intergovernmental Relations, City Financial EMergencies: The Intergovernmental Dimension 33 (1973): "Labor-related costs, including both salary costs and provisions for fringe benefits, constitute 70 to 80 percent of most city budgets."

9 Blechman, supra note 1, at 198, 204.

${ }^{10}$ Id. 10,70 .

${ }^{11}$ See, e.g., H. Wellington \& R. Winter, The Unions and the Cities (1971); 
attributable to civil service laws, which, unlike unionization, are uniquely governmental, have not been adequately subjected to similar scrutiny. Yet most government employees are now protected by civil service, ${ }^{12}$ and the civil service system is a basic cause of the peculiar inability of the government to improve its standard of performance. The critical fact of civil service today is that covered employees are rarely discharged from government for inadequately doing their jobs. ${ }^{13}$ The civil service system has provided the equivalent of life tenure (at least until retirement) once a brief probation period is passed, absent what the government considers a serious act of misconduct. As a result, government no longer effectively enforces a minimum level of quality in the work performance of its employees. Even when the. government is forced to discharge employees because of a budgetary deficit, the initial effort is to protect the jobs of the civil servants at the expense of uncovered workers; the issue is not which particular employees are the most effective in their jobs. ${ }^{14}$ Concern over the effect of this permanent tenure for government employees is widespread. "Virtually every round table discussion of problems facing public managers will quickly turn to the inability of the manager to discipline nonproductive or insubordinate employees or to dismiss those who have ceased

Edwards, The Emerging Duty to Bargain in the Public Sector, 71 MICH. L. REv. 885 (1973); Summers, Public Employee Bargaining: A Political Perspective 83 Yale L.J. 1156 (1974).

${ }^{12}$ See Merrill, Procedures for Adverse Actions Against Federal Employees, 59 VA. L. Rev. 196 (1973): "Today 2.5 million employees, more than 85 percent of the federal workforce, are within the competitive service." Similarly, a 1970 survey conducted by the National Civil Service League found that $96 \%$ of the states, $83 \%$ of the counties, and $84 \%$ of the cities surveyed had civil service systems. Peirce, Proposed Reforms Spark Civil Service Debate, 7 NAT'L J. 1673, 1674 (1975). See generally Kaufman, The Growth of the Federal Personnel System, in The Federal Government Service 41-43 (W. Sayre ed. 1965).

${ }^{13}$ The United States Civil Service Commission reported to me that from 300 to 500 individuals annually, out of a total of more than two million civilian federal employees, were separated for inefficiency by the federal government for the fiscal years 1972-1974. For an example of state experience and reactions thereto, see Osterman \& Austin, New York State's Disciplinary Arbitration Procedure, 47 N.Y. ST. BAR J. 181-83 (1975).

14 Even in the 1975 budget crisis in New York City, the first 5,050 employees to be discharged consisted entirely of "provisional," non-civil service workers. N.Y. Times, June 26, 1975, at 46 , col. 1 . Although as the crisis deepened, the Mayor eventually did discharge some civil servants, N.Y. Times, July 1, 1975, at 1 , col. 8 (dismissals based upon seniority), a number of these were later rehired. N.Y. Times, July 4, 1975, at 1 , col. 8. Whatever the eventual number of workers discharged, it seems doubtful that a judgment about which jobs are most important to the operation of the government will overcome the demand to protect civil service workers first. 
to be productive or constitute chronic supervisory problems." ${ }^{15}$

Strengthening the ability of government managers to ensure adequate employee work performance is an essential ingredient in reforming government administration. Although any large organization has the problem of motivating employees and improving their performance while providing adequate job security, the government today is subject to two basic restrictions of its power over its employees that are inapplicable to private enterprise: It can discipline or discharge its employees only for "cause" and it must provide them with procedural protections in determining the existence of that cause. Of these two limitations, the procedural protections most restrict the government's ability to enforce a standard of job performance. Incompetence is generally assumed to be sufficient "cause" for termination. But the procedures that must be followed to establish incompetence make such terminations extremely unlikely. The problem of adequately defining a standard of competence, particularly in the higher-level and more important jobs, the uncertainty about the kind of evidence needed to prove a violation of that standard, the unpleasant nature of a formal confrontation between people with a personal, empoyer-employee relationship, and the supervisor's view that he, not the employee, will be put on trial-together with the natural reluctance to fire anyone in any event-combine to prevent legitimate discharges for incompetence. The result is that the level of competence in government declines. ${ }^{16}$

Changes in the present personnel removal procedure as a step toward improving the caliber of government personnel,

${ }^{15} \mathrm{~J}$. Macy, Public Service: The Human Side of Government 20 (1971). The author was Chairman of the U.S. Civil Service Commission under President Johnson.

${ }^{16}$ Some writers have said that the allegation of a causal relationship between the procedural requirements for termination and the permanency of tenure in government service contains both "truth and error," $i d$., or is "part real, part imagined," Osterman \& Austin, supra note 13 , at 182 . Whether it is more the supervisor's fears of the procedural requirements than the requirements themselves that prevent discharges cannot, and need not, be determined. In either event, the discharges are not made. The damaging effect of the procedures on the government's personnel management has been documented elsewhere. See, e.g., U.S. Comm'n on Organization of the Executive Branch of the Government, Personnel and Civil Service 67-70 (1955). The allegation that it is in fact easy to discharge employees by present procedures, see, e.g., R. Vaughn, The Spoiled System 14-15 (1975), is rejected by experienced government executives. Interview with William Druz, Chief Examiner, N.J. Civil Service Commission, May 8, 1975. See Laing, Cizil Service Setup, Born as Reform Idea, Now Hit by Reformers, Wall St. J., Dec. 22, 1975, at 1, col. 6. See generally text accompanying notes 239-67 infra. 
however, may not be possible. Since the Supreme Court decisions in Board of Regents $v$. Roth ${ }^{17}$ Perry $v$. Sindermann, ${ }^{18}$ and Arnett $v$. Kennedy, ${ }^{19}$ any consideration of reforming the method of discharging government employees for incompetence must start with a constitutional question: Is the present procedure for discharging employees, entailing a full evidentiary hearing on the issue of competence, constitutionally required? Can any legislation modify the civil service system's present balance between enforcing a level of competence and protecting employee rights? This Article addresses these questions, concluding that despite Roth, Sindermann, and Arnett, the Constitution does permit the Congress and the President to modify the government's personnel removal process. Part II outlines the origins of the executive's power to discharge government employees, the extent to which the civil service system was designed to modify that power, and the judicial role prior to Roth and Sindermann in affecting the employer-employee relationship. Part III analyzes how Roth, Sindermann, and Arnett have changed, or ought to change, the historic role of the courts and the Constitution in reviewing the executive's decision to discharge a government employee considered incompetent.

\section{The Power to Remove Government Employees: The Historical Background}

\section{A. The First Hundred Years}

Efforts to balance the government's flexibility in personnel actions against adequate protection of individual employee rights date from the nation's beginning. On May 19, 1789, during the debate in the first session of Congress over the creation of the first executive department, the Department of Foreign Affairs, Representative James Madison moved that the Secretary of the Department be removable by the President alone. ${ }^{20}$ William Smith of South Carolina objected, arguing that removal should require conviction upon impeachment. ${ }^{21}$ This exchange launched two months of debate on the extent of the President's

17408 U.S. 564 (1972).

18408 U.S. 593 (1972).

19416 U.S. 134 (1974) (plurality decision).

201 ANNals of Cong. 385-86 (1789) [1789-1791] (remarks of Representative Madison).

${ }^{21}$ Id. 387 (remarks of Representative Smith). 
removal powers, a debate "many times described as one of the ablest constitutional debates which has taken place in Congress since the adoption of the Constitution." ${ }^{22}$ The issue of the debate, the balance between the need for security for government employees and the need for their responsiveness to elected officials-between the dangers and the utility of allowing executive discretion in disciplining employees-was central to the creation of the executive's role in the new government.

William Smith was the most forceful advocate for limiting the President's removal power as a protection for the individual's rights, relying on Alexander Hamilton's view of the President's power as expounded in The Federalist, Number $77 .{ }^{23}$ Smith argued that unlimited executive discretion to remove would deter worthy people from accepting office and would make officials once appointed so susceptible to presidential power that they would not dare to challenge abuse of authority:

If we give this power [of removal] to the President, he may, from caprice, remove the most worthy men from office. His will and pleasure will be the slight tenure by which an office is to be held ....

... [I]t ought to be considered, that the person who is appointed will probably quit some other office or business in which he is occupied. Ought he, after making this sacrifice in order to serve the public, to be turned out of place, without even a reason being assigned for such behavior?.. . The public suppose him guilty of malpractices. Hence his reputation is blasted, his property sacrificed. I say his property is sacrificed, because I consider his office as his property. $\mathrm{He}$ is stripped of this, and left exposed to the malevolence of the world, contrary to the principles of the constitution and contrary to the principles of all free Governments, which are, that no man shall be despoiled of his property, but by a fair and impartial trial. ${ }^{24}$

James Madison, the leading advocate of presidential power, replied in a speech that has remained the basic argument for the executive's power of removal:

22 Parsons v. United States, 167 U.S. 324, 329 (1897).

${ }^{23}$ The Federalist No. 77, at 485 (B. Wright ed. 1961) (A. Hamilton); 1 ANnals of CoNG. 474-75 (1789) [1789-1791] (remarks of Representative Smith).

${ }^{24} 1$ ANNALS of Cong. 476 (1789) [1789-1791] (remarks of Representative Smith). 
The danger to liberty, the danger of mal-administration, has not yet been found to lie so much in the facility of introducing improper persons into office, as in the difficulty of displacing those who are unworthy of the public trust. If it is said, that an officer once appointed shall not be displaced without the formality required by impeachment, I shall be glad to know what security we have for the faithful administration of the Government? Every individual, in the long chain which extends from the highest to the lowest link of the Executive Magistracy, would find a security in his situation which would relax his fidelity and promptitude in the discharge of his duty. ...

…

... Vest this power in the Senate jointly with the President, and you abolish at once that great principle of unity and responsibility in the executive department, which was intended for the security of liberty and the public good. ... [I]f anything in its nature is executive, it must be that power which is employed in superintending and seeing that the laws are faithfully executed. ${ }^{25}$

Ultimately, the House of Representatives decisively adopted Madison's approach favoring executive authority, and the Senate agreed, although only by virtue of the tie-breaking vote of the Vice President. ${ }^{26}$ The result, known as the Decision of 1789 , remained the basis of executive power in employee relations, with brief exceptions, until the last thirty years. Even Representative Smith later changed his mind, ${ }^{27}$ as did Hamilton himself. ${ }^{28}$

After the Decision of 1789, the President's absolute power of removal of federal employees was established in principle but was not exercised in fact. Indeed, for the first thirty years of the country's history, with the exception of Jefferson's attempt to modify the political balance of the government work force, ${ }^{29}$

${ }^{25}$ Id. 515-16, 518-19 (remarks of Representative Madison).

${ }^{26}$ Id. 600-08. See D. Rosenbloom, Federal. Service and the Constitution 26-27 (1971) [hereinafter cited as RosENBLOOM].

${ }^{27}$ ROSENBLOOM, supra note 26 , at 29 n.17.

${ }^{28}$ Myers v. United States, 272 U.S. 52, 137 (1926).

${ }^{29}$ Thomas Jefferson could not have been as complacent with the composition of the civil service as his predecessors had been, because he found the entire apparatus of government manned by people loyal to the opposition party, some of whom had been appointed by John Adams in his last days as President. $C f$. Marbury v. Madison, 5 U.S. (1 Cranch) 137 (1803). To redress the political balance of the government, Jefferson 
removals were rare, and those made were for cause. ${ }^{30}$ As the federal service grew considerably during these years, ${ }^{31}$ the tradition was created not only of stability in the federal service but of property in office. As a result, by 1828 the federal service had become unresponsive, inefficient, and filled with sinecures. ${ }^{32}$ Moreover, these employees represented an era not in keeping with the democratic spirit of the times: "When the people voted in 1828 that John Quincy Adams should leave office, they undoubtedly intended to vote that most of the civil servants should go with him."'33

Efforts to revise the concept of property in office and to force government to be more responsive to the electorate preceded the election of 1828 , beginning with the passage of the Tenure of Office Act of $1820 .{ }^{34}$ The Act established a fixed term of four years for a wide variety of federal offices and made clear that removals even within that term were at the pleasure of the President. One purpose of the Act was to overcome the reluctance of executives to discharge employees by having public employees removed automatically, thus not impugning their character. ${ }^{35}$ But neither Monroe, who reluctantly signed the Act, nor John Quincy Adams, who routinely reappointed employees after their terms had expired, used the Act's power. Madison

removed more than $25 \%$ of federal officers of the presidential class and is therefore considered the founder of the spoils system in the United States. C. FISH, THE CiviL Service and the Patronage 42, 51 (1904) [hereinafter cited as Fish]; P. Van Riper, History of the United States Civil Service 23 (1958) [hereinafter cited as VaN RIPER].

${ }^{30}$ President Washington, who had complete freedom to create his own federal service, had little reason to exercise his power of removal. His removals were rare and only for reasons of character or efficiency. FISH, supra note 29, at 13; VAN RIPER, supra note 29, at 19. John Adams continued Washington's practice of providing security of tenure for government employees, although his administration is credited with the first removal for purely political reasons. Fish, supra note 29, at 19 . Once Jefferson had established the new political balance in the government, see note 29 supra, Presidents from his political party-Madison, Monroe, and John Quincy Adams-reaffirmed the tradition of making very few removals for any reason, see Rosenbloom, supra note 26, at 41-42, 65, even though Madison himself had been the instrumental force in asserting the existence of the President's absolute power of removal. F. Mosher, Democracy AND the Public Service 58-59 (1968).

${ }^{31}$ VAN RIPER, supra note 29, at 24.

32 See generally FISH, supra note 29, at 77-78; VAN RIPER, supra note 29, at 33.

${ }^{33}$ Fish, supra note 29 , at 78 .

34 Act of May 15, 1820, ch. 102, 3 Stat. 582.

${ }^{35}$ This purpose was envisioned at least by the Act's principal sponsor, William $\mathrm{H}$. Crawford, President Monroe's Secretary of the Treasury. FISH, supra note 29, at 66-70. The Act also laid the foundation for the principle that each President should have a number of offices to fill every four years, a proposition not previously accepted. 
thought that the Act was unconstitutional, considering it an impermissible congressional incursion into the presidential power to remove (or retain) employees. ${ }^{36}$ Not until Andrew Jackson's election in 1828 did the philosophy of turnover in government become accepted.

Jackson was not the first to fill public offices for political reasons; political appointments had been made commonly in a number of states ${ }^{37}$ and occasionally on the federal level. He was, however, the first President to do so avowedly as a means of reform of governmental policy. In his first annual message, he articulated the need for a politically responsive turnover of the public service:

Offices were not established to give support to particular men at the public expense. No individual wrong is, therefore, done by removal, since neither appointment to nor continuance in office is a matter of right. The incumbent became an officer with a view to public benefits, and when these require his removal they are not to be sacrificed to private interests. . . . [Acceptance of this view] would destroy the idea of property now so generally connected with official station, and although individual distress may be sometimes produced, it would, by promoting that rotation which constitutes a leading principle in the republican creed, give healthful action to the system. ${ }^{38}$

Jackson's efforts to change the composition of the federal service were circumspect. His removals, although substantial, probably totaled no more than twenty percent of federal employees. ${ }^{39}$ Even so, his exercise of presidential power met considerable opposition in the Congress and reopened the debate over the

36 Id. 67.

37 See generally id. 79-104.

382 A Compilation of the Messages and Papers of the Presidents, 1789-1897, at 449 (J. Richardson ed. 1898). Jackson viewed the automatic rotation of government offices as one possibility:

I can not but believe that more is lost by the long continuance of men in office than is generally to be gained by their experience. I submit, therefore, to your consideration whether the efficiency of the Government would not be promoted and official industry better secured by a general extension of the law which limits appointments to four years.

Id. See Fish, supra note 29, at 111-12.

${ }^{39}$ Rosenbloom, supra note 26, at 54. Jackson did, however, remove 252 out of 610 presidential officers. Id. 
proper extent of the President's removal power. Daniel Webster attacked the finality of the Decision of 1789; John C. Calhoun recommended the repeal of the Tenure of Office Act of 1820 and proposed a requirement that the President inform the Senate of reasons for a removal; Henry Clay introduced a resolution suggesting that removals be made only with the concurrence of the Senate. ${ }^{40}$ But efforts to curb the President's removal power died in the House of Representatives. ${ }^{41}$

The rapid changes of presidency and party in the twentyfive years following Jackson's administration may help to explain why the spoils system became the routine of American politics during that period. As the years passed, the size and scope of political removals increased; people seeking jobs filled the capital after each election. ${ }^{42}$ Finally, with the election of the Republican Lincoln in 1860, the removals reached their peak: 1457 of the 1639 presidential appointees were replaced. ${ }^{43}$ The tradition of tenure had been replaced by a tradition of turnover.

Although several statutes of limited scope were enacted during Lincoln's administration to assert a legislative check on executive patronage power, ${ }^{44}$ congressional fear of President Andrew Johnson's use of the removal power occasioned the first major reversal of the traditional reliance on executive discretion in removals, the Tenure of Office Act of 1867.45 The Act was intended not as a bulwark of individual rights, but as a congressional effort to establish its own power against the President. The Act provided that individuals appointed by the President with the advice and consent of the Senate could be removed only with the concurrence of the Senate. ${ }^{46}$ President

${ }^{40}$ FISH, supra note 29, at 141-42; VAN RIPER, supra note 29, at 39-40.

41 VAN RIPER, supra note 29 , at $40-41$.

${ }^{42}$ Although relative stability continued under Van Buren (who was, like Jackson, a Democrat), the Whigs were elected in 1841, and they decided to follow Jackson's precedent by removing a large number of people on political grounds. The Whigs were replaced by the Democrats in 1845 , who were replaced by the Whigs in 1849 , with the Democrats returning in 1853. Each election produced a substantial turnover in government. Even James Buchanan, who succeeded a fellow Democrat, removed a large number of employees, expanding the spoils system to comprehend the routine transfer of government jobs to those loyal to the newly elected President. See FISH, supra note 29 , at $143-72$.

${ }^{43}$ Id. 170 .

${ }^{44}$ Id. 187.

45 Act of Mar. 2, 1867, ch. 154, 14 Stat. 430.

${ }^{46}$ The President had the power only to suspend the appointees pending Senate action. Id. \$2. 
Johnson vetoed the bill as unconstitutional, citing the unbroken history of sole presidential power of removal; Congress overrode his veto. ${ }^{47}$ Expecting to force a judicial resolution of the constitutionality of this congressional limitation of the President's removal powers, Johnson, on May 13, 1867, suspended Secretary of War Stanton and, without making reference to the Tenure of Office Act, notified the Senate of this action. The Senate, pursuant to the Act, refused to agree to the suspension on January 13, 1868, and on February 21, Johnson announced Stanton's removal and replacement. The House at once proceeded to impeach the President but the Senate refused to convict, influenced in part by the failure of the literal wording of the Act to protect Stanton. ${ }^{48}$

The constitutional crisis over the Tenure of Office Act of 1867 raised anew the fundamental question posed by Madison in the 1780's and by Jackson in the 1830's: Should the President have unlimited authority to remove his appointees? Judicial affirmation of presidential power did not come until $1926,{ }^{49}$ and, during the period of constitutional uncertainty following Johnson's acquittal, Congress continued its legislative efforts to limit presidential power. ${ }^{50}$ But because the Senate rarely exercised the power given by legislation to overturn a President's removal (although it frequently rejected presidential appointments), the practice of the President alone removing his employees largely survived the battle over the Tenure of Office Act of 1867.51 Meanwhile, the battleground over the President's powers over government employment shifted from limitations of the President's power to remove employees to limits on his power to appoint them. The Tenure of Office Act of 1867 be-

${ }^{47}$ See Cong. Grobe, 39th Cong., 2d Sess. 1977 (1867); Fish, supra note 29, at 197.

48 Originally, the bill exempted cabinet officers altogether, but because of pressure by the House, the final bill provided that cabinet officers would hold office for the term of the President who appointed them and a month thereafter, subject to removal by and with the advice and consent of the Senate. Fish, supra note 29, at 196-97. Appointment or removal contrary to the Act was specifically declared to be a "high misdemeanor." Act of Mar. 2, 1867, ch. 154, § 9, 14 Stat. 431. Stanton, however, had been appointed by Lincoln and not by Johnson. See Fish, supra, at 198-201.

${ }^{49}$ Myers v. United States, 272 U.S. 52, 164-68 (1926); see text accompanying notes 106-17 infra.

50 The Tenure of Office Act was not repealed for 20 years, Act of Mar. 3, 1887, ch. 353, 24 Stat. 500, and other similar laws were enacted, e.g., Act of July 12, 1876, ch. $179, \S 6,19$ Stat. 80 (appointment and removal of postmasters). See Fish, supra note 29, at 201-08.

${ }^{51}$ Fish, supra note 29, at 201-04. 
came, at least to its defenders, merely a step toward civil service reform..$^{52}$

\section{B. Civil Service Reform}

The civil service reform movement, which consisted of efforts to establish standards for appointment to government service, began with several bills introduced in the mid-1860's. ${ }^{53}$ In 1871 , the movement succeeded in obtaining congressional enactment of a rider to an appropriation bill, authorizing (though not requiring) the President to prescribe rules for admission into the civil service. ${ }^{54}$ President Grant immediately implemented the bill by appointing a Civil Service Commission. ${ }^{55}$ The Commission lasted only three years, however, because Congress was unwilling to provide money to support it and the President was willing to let the matter drop. ${ }^{56}$ Efforts to create a permanent civil service system remained unsuccessful until after the assassination of President Garfield by a disappointed office seeker in 1881; the momentum created by the assassination contributed to the passage of the Pendleton Act of $1883 .{ }^{57}$

The cornerstone of the Pendleton Act was the provision concerning open competitive examinations for entrance into the public service. ${ }^{58}$ The Act did not require the President to appoint people according to examination results; he was authorized merely to request the help of the Civil Service Commission (rather than a political machine) to screen candidates for public jobs. He could apply the civil service rules where he saw fit. ${ }^{59}$ The most striking fact about the Pendleton Act, however,

52 See Myers v. United States, 272 U.S. 52, 276-77 (Brandeis, J., dissenting).

${ }^{53}$ VAN RIPER, supra note 29 , at 65-67.

${ }^{54}$ Act of Mar. 3, 1871, ch. 114, § 9, 16 Stat. 514.

${ }^{55}$ Many of the rules adopted by the Commission continue taday to be the foundation of the Civil Service System. VAN RIPER, supra note 29, at 69-70.

${ }^{56}$ Id. 71 .

${ }^{57}$ Act of Jan. 16, 1883, ch. 27, 22 Stat. 403; see VAN RIPER, supra note 29, at 89-94.

${ }^{58}$ Act of Jan. 16, 1883, ch. 27, § 2, 22 Stat. 403.

59 The permissive nature of the Act was probably a result of the 1871 opinion of Attorney General Akerman that any restriction on the President's discretion in appointment would be unconstitutional. Akerman reasoned that the Constitution gave the President power to "appoint" and thereby required him to exercise judgment and discretion. If Congress required the President to appoint an individual selected by a process designed by a Civil Service Commission, the President's appointing power would be unconstitutionally denied him. 13 OP. ATT'Y GEN. 516 (1871); see VAN RIPER, supra note 29, at 106-07; Kaufman, supra note 12, at 38. In fact, the civil service selection provisions of the Act did not adopt the merit system exclusively. They provided for apportioning offices among the states on the basis of population, gave preference to veterans 
was that it did not restrict the President's general power to remove employees. ${ }^{60}$ Congress thought it unnecessary to reopen the longstanding constitutional struggle over Congress' ability to limit the President's removal power. If civil service restrictions prevented the President from appointing a hand-picked replacement for a person he removed, his incentive to remove for political reasons would disappear. ${ }^{61}$ Moreover, even the most vigorous defenders of the civil service concept felt that a limit on the removal power would be unwise. George William Curtis, the foremost advocate of civil service reform and the Chairman of Grant's Civil Service Commission, ${ }^{62}$ argued:

Having annulled all reason for the improper exercise of the power of dismissal, we hold that it is better to take the risk of occasional injustice from passion and prejudice, which no law or regulation can control, than to seal up incompetency, negligence, insubordination, insolence, and every other mischief in the service, by requiring a virtual trial at law before an unfit or incapable clerk can be removed. ${ }^{63}$

The purpose of civil service reform was to limit the quadrennial turnover of government resulting from the spoils system; the reform movement did not otherwise seek to limit the President's ability to remove employees he considered unfit. Even the Civil Service Commissioners had no term and could be removed by the President at will. ${ }^{64}$

Coverage under the civil service system grew rapidly, although not always as a result of belief in the principle of merit selection. ${ }^{65}$ By 1896 , almost half of the federal service-about

in selection, and limited the number of employees from any particular family. Act of Jan. 16, 1883, ch. $27, \S \S 2,7,9,22$ Stat. $404,406$.

${ }_{60}$ The Act did prohibit removing employees for giving or refusing to give political contributions. Act of Jan. 16, 1883, ch. 27, § 13, 22 Stat. 407. Otherwise, the Act did not place any limits on the executive power of removal.

${ }_{61}$ Rosenbloom, supra note 26, at 87-88; VAN RIPER, supra note 29, at 102.

62 VAN RIPER, supra note 29, at 69.

${ }^{63}$ Quoted in VAN RIPER, supra note 29, at 102 (footnote omitted).

${ }^{64}$ Act of Jan. 16, 1883, ch. 27, preamble, 22 Stat. 403.

${ }^{65}$ The first election after the passage of the Pendleton Act resulted in a victory for Grover Cleveland, the first Democrat to hold the Presidency in a quarter of a century. Once the election returns were in, the outgoing President, Chester Arthur, added more than a thousand positions to the civil service, thus protecting the (Republican) incumbents by limiting the victor's incentive to remove them. This process of "covering in" employees to protect patronage incumbents after the election, thereby limiting the flexibility of future Presidents but not of the outgoing incumbent, was the major factor in 
the limit reformers had thought possible under a merit system-was under civil service protection. ${ }^{66}$ Moreover, the Civil Service Commission recognized that unjustified removals had largely disappeared within the classified civil service, while they remained substantial in the unclassified federal service. ${ }^{67}$ But beginning in 1887, the Commission sought a presidential order requiring that the reason for removal be specified and made part of the record of the department making the removal. ${ }^{68}$ Such a requirement, it thought, would further deter unjustified political removals. President Cleveland refused to issue such an order, ${ }^{69}$ but on July 27, 1897, President McKinley not only did so, but went further, directing that "[n]o removal shall be made from any position subject to competitive examination except for just cause and upon written charges filed with the head of the department or other appointing officer, and of which the accused shall have full notice and an opportunity to make defense." 70

The Civil Service Commission did not intend that the addition to the civil service concept that removal be based on "cause" become a limit on the power of the executive to remove unqualified employees. Rather it saw the Executive Order as meaning merely that the executive had to have a legitimate, non-political reason for removal. ${ }^{71}$ The Commission recognized, however, that the provision could be interpreted to mean that a trial would be necessary to determine the existence of "cause." The Commission opposed this interpretation, arguing that "to require this would not only involve enormous labor, but would give a permanence of tenure in the public service quite inconsistent with the efficiency of that service." 72 It therefore recommended to President Roosevelt, himself a former Civil Service Commissioner, ${ }^{73}$ that the rule be clarified. On May 29, 1902, Roosevelt issued a clarifying Executive Order:

the doubling of the coverage of the Civil Service in the first decade of the Pendleton Act. Cleveland, however, made a major extension of Civil Service coverage during the course of his second term. VAN RIPER, supra note 29, at I17-18, 122.

${ }^{66} \mathrm{Id} .126,130$.

6713 U.S. Civ. Serv. Comm'n ANn. Rep. 19 (1897).

6815 U.S. Giv. Serv. Comm'n ANN. ReP. 19 (1899).

${ }^{69}$ Id.

${ }^{70}$ Quoted in 14 U.S. Crv. Serv. Comm'n Ann. ReP. 24 (1898).

7119 U.S. Civ. SERv. COMM'N ANN. REP. 18-19 (1902).

72 Id. 18.

${ }^{73}$ Van Riper, supra note 29, at 124 n.18; see A. Sageser, The First Two Decades 
Now, for the purpose of preventing all such misunderstandings and improper constructions of said section, it is hereby declared that the term "just cause," as used in section 8, Civil Service Rule II, is intended to mean any cause, other than one merely political or religious, which will promote the efficiency of the service; and nothing contained in said rule shall be construed to require the examination of witnesses or any trial or hearing except in the discretion of the officer making the removal..$^{74}$

Although Roosevelt later sought to reduce the protection the Orders had given to civil servants, ${ }^{75}$ President Taft issued an Executive Order in 1912 reaffirming the two original Orders. ${ }^{76}$

In its annual report of 1912, the Civil Service Commission explained why the Taft Executive Order continued to require only notice and a right to reply, and not a trial, prior to an employee removal:

The rules are not framed on a theory of life tenure, fixed permanence, nor vested right in office. It is recognized that subordination and discipline are essential, and that therefore dismissal for just cause shall be not unduly hampered. ... Appointing officers, therefore, are entirely free to make removals for any reasons relating to the interests of good administration, and they are made the final judges of the sufficiency of the reasons. ...

... The rule is merely intended to prevent removals upon secret charges and to stop political pressure for removals. . . . No tenure of office is created except that based upon efficiency and good behavior; and it remains as much the duty of an appointing officer to remove a classified employee for inefficiency as it is not

of the Pendleton Act: A Study of Civil Service Reform 141-43 (1935) (analyzing T. Roosevelt's performance as a Civil Service Commissioner).

${ }^{74}$ Quoted in 19 U.S. Civ. Serv. Comm'n ANN. ReP. 76 (1902).

${ }^{75}$ In 1905, Roosevelt weakened the original Order, making the giving of notice to discharged employees discretionary, 22 U.S. Civ. SERv. CoMM'N ANN. REP. 71 (1905), but the change made little practical difference, 29 U.S. Crv. SERv. Comm'N ANN. REP. 22 (1913). See note 76 infra \& accompanying text.

${ }_{76} 29$ U.S. Civ. Serv. Comm's Ans. ReP. 132-33 (1913). The Order restored the original rule requiring notice and a right to reply specifying, however, that "no examination of witnesses nor any trial or hearing shall be required except in the discretion of the officer making the removal." Id. 132. 
to discriminate against him in any way for political or religious reasons. ${ }^{77}$

Shortly after Taft issued his Executive Order, Congress began to debate a rider to the Post Office appropriations bill of 1912, which, in part, gave statutory authority to the provisions of the Executive Order and was phrased in almost identical words. ${ }^{78}$ The final bill, known as the Lloyd-LaFollette Act, was enacted and signed into law on August 24, 1912. ${ }^{79}$ This codification of President Taft's Executive Order remains today the governing statute for all removals of employees from the federal civil service except those of veterans. ${ }^{80}$ Nothing in the legislative history of the Lloyd-LaFollette Act questioned the unwillingness reflected in the Executive Order to require the executive to "prove" he had cause prior to discharging a civil servant. Indeed, the Act's adoption of the language of prior Executive Orders specifying that no hearing would be required, thus limiting the employee's rights to notice and a right to a reply, indicates quite the contrary. Civil service rules, therefore, continued to prohibit only certain impermissible grounds for removal and otherwise allowed the executive to define "cause." 81 The legislative and

\begin{abstract}
${ }^{77}$ Id. $21-22$.
${ }^{78}[\mathrm{~N}] \mathrm{o}$ person in the classified civil service of the United States shall be removed therefrom except for such cause as will promote the efficiency of said service and for reasons given in writing, and the person whose removal is sought shall have notice of the same and of any charges preferred against him, and be furnished with a copy thereof, and also be allowed a reasonable time for personally answering the same in writing; and affidavits in support thereof; but no examination of witnesses nor any trial or hearing shall be required except in the discretion of the officer making the removal; and copies of charges, notice of hearing, answer, reasons for removal, and of the order of removal shall be made a part of the records of the proper department or office, as shall also the reasons for reduction in rank or compensation; and copies of the same shall be furnished to the person affected upon request, and the Civil Service Commission also shall, upon request, be furnished copies of
\end{abstract} the same ....

Act of Aug. 24, 1912, ch. 389, § 6, 37 Stat. 555.

Congressional debate, however, did not focus on the implications of this removal procedure, but concentrated instead on reversing the attempts of Presidents Roosevelt and Taft to allow civil servants to communicate with Congress only through department heads, the so-called "gag rules." The Senate also sought the protection of the rights of the employees to organize collectively. 48 Conc. REc. 5625-27, 5632-39, 9952-53, $10670-77,10728-33$ (1912). These matters were specifically covered by provisos. Act of Aug. 24, 1912, ch. 389, § 6, 37 Stat. 555.

${ }^{79}$ Act of Aug. 24, 1912, ch. 389, § 6, 37 Stat. 555, as amended, 5 U.S.C. §§ 7101, 7102 (1970).

${ }^{80} 5$ U.S.C. \& 7501 (1970).

${ }^{81}$ The development of Civil Service Rule XII, concerning removals, is reported in the Annual Reports of the Civil Service Commission and, more recently, in separately 
executive branches continued to affirm the importance of executive discretion as established by the Decision of 1789 , a joint position broken only by the constitutional crisis over the Tenure of Office Act of 1867.

Beginning in the early 1930's, however, the Civil Service Commission began to seek a role in reviewing the discretion exercised by the agencies in employee dismissals and urged the creation of an appellate process within the Civil Service Commission. ${ }^{82}$ No action was taken on this proposal until the passage of the Veterans' Preference Act of $1944 .{ }^{83}$ Section 14 of the $\mathrm{Act}^{84}$ provided veterans thirty days' notice of any adverse action against them; afforded them the right of a personal appearance to challenge the action, rather than merely a right to a written reply as under the Lloyd-LaFollette Act of 1912; and, most importantly, afforded veterans the right to appeal to the Civil Service Commission "from an adverse decision ... of an administrative authority. ..."85 The genesis of this dramatic departure from the historic emphasis on executive discretion is obscure. The House report on the bill ${ }^{86}$ and the very brief House debate ${ }^{87}$ focused solely on the wartime concern with providing adequate employment opportunities for returning veterans and did not explain the need for the procedural changes made by Section 14. There was no Senate debate on the bill. ${ }^{88}$ Section 14 might be explained, however, simply by the Act's pervasive emphasis on giving veterans a decisive break in employment opportunities, a break which was too important to be entrusted to executive discretion. Given the protective legislative scheme as to hiring, promotion, and layoffs, ${ }^{89}$ it is not surprising

issued annual compilations of current Civil Service Rules. See, e.g., 42 U.S. Crv. SERv. COMM'N ANN. ReP. 7 I (1925).

8248 U.S. Civ. Serv. Comm'n Ann. Rep. 41 (1931). See Guttman, The Development and Exercise of Appellate Powers in Adverse Action Appeals, 19 AM. U.L. REv. 323, 332 (1970).

${ }^{83}$ Act of June 27, 1944, ch. 287, 58 Stat. 387.

${ }^{84} 5$ U.S.C. $\$ \S 7511,7512,7701(1970)$. The benefits of section 14 are afforded "preference eligibles" as defined in 5 U.S.C. $\$ 2108(3)$ (1970), as amended, (Supp. IV, 1974). The term includes, in addition to veterans, the unmarried widows or widowers of veterans, the wives or husbands of certain disabled veterans, and the mothers of certaln veterans. See also 5 U.S.C. \$ 7511 (1970). I use the term "veteran" in this Article to include all preference eligibles.

${ }^{85} 5$ U.S.C. \& 7701 (1970).

${ }^{86}$ H.R. REP. No. 1289, 78th Cong., 2d Sess. (1944).

8790 CoNG. Rec. $3501-06$ (1944).

${ }^{88}$ Id. 5784-85 (1944).

${ }^{89}$ To ensure appointment of veterans, the Act first listed a number of specific ad- 
that an agency's discretion to remove veterans for cause was also subject to Civil Service Commission review.

Once the veterans' rights to an appellate process were established, however, there seemed to be an incongruity between having a review process for removal of veterans, who constituted more than fifty percent of the federal civil service, and having no review process for the remaining federal employees. ${ }^{90}$ Some called for the establishment of a single federal procedure by extending the principles of the Veterans' Preference Act of 1944 to all civil service employees, ${ }^{91}$ but others preferred making the Lloyd-LaFollette Act procedures universally applicable. Thus, in its review of needed reforms in the organization of the federal government, the second Hoover Commission called for a return to the provisions of the Lloyd-LaFollette Act of 1912, criticizing the procedures under section 14 of the Veterans' Preference Act. That section, said the Commission, "creates serious problems for management, unduly hampers operations, and . . produce[s] quite the opposite of good employer-employee relationships."92

Shortly after assuming office, President Kennedy appointed a task force to establish a policy for employee-management cooperation in the federal service which would deal with a number of problems of federal government employees, including the right to appellate review of adverse actions. The committee recommended that the President extend the Veterans' Preference Act rights to all civil service employees. ${ }^{93}$ On January 17 ,

vantages afforded them: It augmented their earned ratings for appointment by a specified amount to ensure advantage over otherwise equal non-veterans, Act of June 27, 1944 , ch. 287, $\S 3,58$ Stat. 388 ; it specified the type of experience for which they were to receive credit toward appointment, id. $\S 4$; it mandated the waiving of nonessential age, height, and weight requirements for them only, id. $\S 5$. The Act then went on to require that veterans be placed at the top of the list in accordance with their augmented ratings, id. $\S 7$, and that a statement in writing be made of the reasons any non-veteran was selected over an eligible veteran, with the Civil Service Commission directed to determine the sufficiency of such reasons, id. $\S 8$. To ensure that veterans were protected from layoffs, the Act required that any veteran whose efficiency rating was good or better had to be retained in preference to all other employees, and that veterans whose efficiency ratings were below good had to be retained in preference to all other employees of equal or lower rating, id. $\S 12$.

${ }^{90}$ See H.R. ReP. No. 1844, 84th Cong., 2d Sess. 45-46, 58 (1956); H.R. REP. No. 1759, 83d Cong., 2d Sess. 21 (1954); S. Doc. No. 33, 83d Cong., Ist Sess. 7-9 (1953).

${ }^{91}$ H.R. ReP. No. 1759, 83d Cong., 2d Sess. 21-22 (1954); S. Doc. No. 33, 83d Cong., 1st Sess. 8-9, 26 (1953).

92 U.S. Commission on Organization of the Executive Branch of the GovernMENT, supra note 16 , at 68 .

${ }^{93}$ President's Task Force on Employee-Management Relations in the Federal 
1962, President Kennedy issued an Executive Order establishing a system of appeals within each agency for review of adverse actions and requiring that the appellate process provide a hearing to the employee. ${ }^{94}$ President Nixon supplemented this procedure with a right to appeal to the Civil Service Commission itself, thereby giving non-veterans the same rights veterans had under the Veterans' Preference Act. ${ }^{95}$ On June 11, 1974, President Nixon made appeal to the Civil Service Commission the sole possible appeal, revoking the agency review process established by President Kennedy. ${ }^{96}$ The right of every civil servant to an outside appraisal of the grounds for dismissal has thus recently replaced the historic emphasis on executive discretion.

\section{The Role of the Courts}

\section{Prior to Bailey v. Richardson}

Until the 1950's the courts consistently refused to review challenges to the executive's power to remove employees. This refusal has often been attributed to a "doctrine of privilege," the notion that the government has unlimited power over its employees because government employment is a privilege and not a right. ${ }^{97}$ In fact, the doctrine of privilege has not been the basis for denying judicial relief to affected employees, at least in the federal courts. Rather, the United States Supreme Court has relied on three other doctrines: that the power to remove employees is inherent in and necessary to the constitutional grant of executive authority; that one legislature cannot bind another in defining the nature of executive positions; and that

Service, A Policy for Employee-Management Cooperation in the Federal Service 24 (1961).

${ }_{94}$ Exec. Order No. 10,987, 3 C.F.R. 519 (Comp. 1959-1963), 5 U.S.C. $\$ 7501$ (1970). For a discussion of the impact of this order, see Berzak, Rights Accorded Federal Employees Against Whom Adverse Personnel Actions Are Taken, 47 Notre Dame Law. 853 (1972).

${ }^{95}$ Exec. Order No. $11,491, \S 22,3$ C.F.R. 266 (1974), 5 U.S.C. $\$ 7301$ (1970). 1974).

${ }^{96}$ Exec. Order No. 11,787, 3A C.F.R. 151 (1974), 5 U.S.C. $\$ 7701$ (Supp. IV,

${ }_{97}$ See, e.g., Rosenbloom, supra note 26, at 16; Comment, Fear of Firing: Arnett v. Kennedy and the Protection of Federal Career Employees, 10 Harv. Civ. Rights-Civ. Lib. L. Rev. 472, 478 (1975). See generally Van Alstyne, The Demise of the Right-Privilege Distinction in Constitutional Law, 81 HARv. L. REv. 1439 (1968). The doctrine stems from Justice Holmes' famous epigram, "The petitioner may have a constitutional right to talk politics, but he has no constitutional right to be a policeman." McAuliffe v. Mayor of New Bedford, 155 Mass. 216, 220, 29 N.E. 517 (1892). 
the kind of issues that arise in employment disputes are not proper subjects for judicial resolution.

The judicial conception of the importance of employee removals to the exercise of executive power has been the principal basis for the refusal to overturn employee discharges. In 1839, the Supreme Court first dealt with an employee dismissal in $E x$ parte Hennen, ${ }^{98}$ a case concerning a judicial, not an executive, employee. The Court upheld the right of a district court judge to remove his clerk in order to replace him with an old friend. Although the statute creating the office of clerk did not expressly provide a power of removal, Congress had expressed no intention that clerks would serve for life. In light of the constitutional and congressional silence, the Court reasoned that "it would seem to be a sound and necessary rule, to consider the power of removal as incident to the power of appointment."99 Since life tenure would not be assumed, the discretion of the appointing officer could be the only basis for removal, leaving no role in the removal process for the courts.

Some sixty years later, in Parsons $v$. United States, ${ }^{100}$ the Court upheld the President's right to remove a district attorney appointed under a statute providing for a four-year term, even though the removal preceded the expiration of his term. This case presented the Court with what could be interpreted as an attempt by Congress to limit the President's removal power by establishing a fixed term of office. The Court's refusal to interpret the statute as such a limitation was based on two fundamental premises. First, the Court wanted to avoid deciding the question, raised by the Tenure of Office Act of 1867 and the Johnson impeachment, whether Congress could constitutionally limit the President's power of removal. Second, the Court's review of the history of the removal power since the Decision of 1789 suggested that such a power was so important to the exercise of the executive authority that any attempted limitation would have to be specified in the clearest possible terms. The Parsons Court thus interpreted the statute specifying a four-year term as "an act of limitation not of grant": ${ }^{101}$ The term was established as a maximum length of service to which the appointee was entitled,

9838 U.S. (13 Pet.) 230 (1839).

${ }^{99} I d$. at 259.

100167 U.S. 324 (1897).

${ }^{101}$ Id. at 338. 
allowing the President to remove the appointee earlier, at his pleasure. ${ }^{102}$

The Parsons approach had its broadest application in Shurtleff $v$. United States, ${ }^{103}$ in which the Court upheld the President's removal of a general appraiser without specified reasons despite a statute that provided that appraisers "may be removed from office at any time by the President for inefficiency, neglect of duty, or malfeasance in office. . ." 104 The Court, refusing to consider congressional specification of the reasons for removal as a limit on the President's ability to remove at his pleasure, strained to find a reason supporting such a result. It interpreted the statute as an attempt to make clear that a removal for unspecified reasons would create a conclusive presumption that the removal was not for any of the causes named in the statute, and therefore could not be regarded as based upon the employee's integrity or capacity. ${ }^{105}$

In 1926, the Supreme Court was squarely faced with the question it sought to avoid in Parsons and Shurtleff: Was the Decision of 1789 giving the President the sole power to remove his appointees merely a matter of legislative choice by the First Congress, subject to reversal by a later Congress, or was it constitutionally compelled? In Myers $v$. United States, ${ }^{106}$ a postmaster, removed from office by action of the Postmaster General, sued for his salary from the date of his removal. He argued that his removal was illegal under the 1876 Act creating his office, which provided that he could be appointed and removed only "by and with the advice and consent of the Senate."107 The Court re-

${ }^{102}$ Similarly, in Reagan v. United States, 182 U.S. 419 (1901), the Court upheld the removal of a commissioner in the Indian Territory by the court that had appointed him when the statute provided that commissioner could be removed "for causes prescribed by law." Id. at 424 . Although neither the executive nor Congress had specified any such causes, the Court, citing Hennen and Parsons, held that a removal without specification of any cause was proper because the statute could not have been intended to limit the power of removal incident to the power of appointment.

${ }^{103} 189$ U.S. 311 (1903).

${ }^{104}$ Act of June 10,1890 , ch. $407, \S 12,26$ Stat. 136; see 189 U.S. at 313.

105189 U.S. at 317.

A removal for [the causes listed in the statute] can only be made after notice and an opportunity to defend, and therefore, if a removal is made without such notice, there is a conclusive presumption that the officer was not removed for any of those causes, and his removal cannot be regarded as the least impuId. tation on his character for integrity or capacity.

106272 U.S. 52 (1926).

${ }^{107}$ Act of July 12,1876 , ch. $179, \S 6,19$ Stat. 81. 
jected the postmaster's argument, holding that the sole executive power of removal could not be limited by Congress.

The opinion, written by Chief Justice (and former President) Taft, relied heavily on Madison's arguments for presidential authority to remove made at the time of the Decision of $1789 .{ }^{108}$ The power of removal, the Court reasoned, was inherently an executive power, not a legislative or judicial function. The Constitution by its terms limits the requirement of Senate concurrence to appointments, because a limitation on removals would be a much greater restriction on presidential power. The rejection of a nominee enables the Senate to prevent the appointment of a bad person to government and limits the President only by forcing him to select another person entirely of his own choosing. On the other hand, a Senate rejection of an attempted removal would force the President to retain a person not of his own choosing. The Constitution was not designed to give Congress the power, in the case of a political difference with the President, to thwart his authority "by fastening upon him, as subordinate executive officers, men who by their inefficient service under him, by their lack of loyalty to the service, or by their different views of policy, might make his taking care that the laws be faithfully executed most difficult or impossible."109

The power to prevent the removal of an officer who has served under the President is different from the authority to consent to or rejece his appointment. When a nomination is made, it may be presumed that the Senate is, or may become, as well advised as to the fitness of the nominee as the President, but in the nature of things the defects in ability or intelligence or loyalty in the administration of the laws of one who has served as an officer under the President, are facts to which the President, or his trusted subordinates, must be better informed than the Senate, and the power to remove him may, therefore, be regarded as confined, for very sound and practical reasons, to the governmental authority which has administrative control. The

${ }^{108}$ See text accompanying note 25 supra.

109272 U.S. at 13I. Justice McReynolds, in dissent, disagreed with the majority's interpretation of the facts as well as of the meaning of the Decision of 1789, arguing that Congress did not intend by its actions to grant unlimited powers to the President to remove his appointees. Id. at 193-204 (McReynolds, J., dissenting). 
power of removal is incident to the power of appointment, not to the power of advising and consenting to appointment, and when the grant of the executive power is enforced by the express mandate to take care that the laws be faithfully executed, it emphasizes the necessity for including within the executive power as conferred the exclusive power of removal. ${ }^{110}$

The Court concluded that the congressional attempt to require Senate concurrence in the removal of postmasters, like the broader attempt to limit the President's removal power by the Tenure of Office Act of 1867, was unconstitutional. ${ }^{111}$ The second premise of the Parsons decision, that the power of removal is inherent in executive power, thus became the answer to the constitutional question the Parsons Court had sought to avoid.

The Myers Court tried to limit its sweeping affirmation of the sole executive power of removal by relying on the Constitution's distinction between executive officers appointed by and with the advice and consent of the Senate and those whose appointment Congress can vest in the executive alone. ${ }^{112}$ The Court reasoned that Congress can limit the removal of officers whose appointment it has vested in the executive alone because all executive power over those officers was derived in the first instance from Congress. Thus Congress can condition its grant of power to the executive on whatever terms it thinks appropriate. ${ }^{113}$ On the other hand, the President's power to appoint officers with the concurrence of the Senate is derived not from Congress but from the Constitution itself. Congress therefore has no analogous authority to limit the executive power over these officers. ${ }^{114}$ In emphasizing the importance of the ap-

\footnotetext{
110 Id. at 121-22.

${ }^{111} \mathrm{Id}$. at 164-72, 176.

112 [The President] shall nominate, and by and with the Advice and Consent of the Senate, shall appoint Ambassadors, other public Ministers and Consuls, Judges of the supreme Court, and all other Officers of the United States, whose Appointments are not herein otherwise provided for, and which shall be established by Law: but the Congress may by Law vest the Appointment of such inferior Officers, as they think proper, in the President alone, in the Courts of Law, or in the Heads of Departments.
}

U.S. Consr. art. II, $\S 2$, cl. 2.

113272 U.S. at 159-61. This reasoning was based on United States v. Perkins, 116 U.S. 483 (1886), in which the Court upheld the power of Congress to condition the removal of a naval officer-whose appointment Congress vested in the Secretary of the Navy alone - on a court martial prior to removal.

114272 U.S. at $163-64$. 
pointment process in determining the extent of congressional power over removals, the Court specifically rejected the notion that the congressional power always exists where the office is an inferior one. ${ }^{15}$ As Madison recognized in 1789, the concept of responsiveness to executive authority must be accepted through the entire spectrum of those exercising that authority. ${ }^{116}$ The President cannot govern by controlling his Cabinet alone; they too must control their departments to be able to carry out the President's decisions.

The Court's own emphasis on the importance of the removal power to executive authority, however, undermines its reliance on the appointment process as the test of determining the power of Congress over removals. As the Court itself acknowledged, its reasoning would seem to allow Congress to gain control of the removal process simply by vesting sole power of appointment in the executive. ${ }^{117} \mathrm{~A}$ strong argument can be made that this weakening of executive power is not constitutionally compelled. As with appointments made with the Senate's concurrence, the constitutional provision giving Congress authority to vest sole appointment power in the executive refers only to appointments and not to removals. The section on its face allows Congress to choose to participate or not to participate in the appointment process for inferior officers; it does not authorize Congress to interfere in the executive personnel process in any other way. If the removal power is truly executive in nature, as the Court argued, it seems no less so because Congress

${ }^{115} I d$. at 158-61. Even though the Constitution grants Congress the authority to vest the power of appointment for "inferior offices," note 112 supra, and the position of postmaster seems inferior in the overall scheme of governmental power, the Court held that congressional participation in the appointment process for that office classified it as one appointed "by and with the advise and consent of the Senate" and thereby prevented Congress from limiting the President's power of removal.

The Court's reliance on the appointment process enabled it to suggest how the Civil Service System was constitutionally valid. Any congressional limitation on removals under a Civil Service System would be constitutional, the Court said, as long as it did not apply to officials appointed with the concurrence of the Senate. 272 U.S. at 173-74.

${ }_{116}$ See text accompanying note 25 supra. Having rejected the argument of the majority that control over subordinates is necessary to executive authority, dissenting Justices $\mathrm{McReynolds}$ and Brandeis argued that the appropriate factor in ascertaining the scope of the executive power is whether the office was a superior or inferior one, and, without deciding the extent of the power of the President to remove a Cabinet officer, said that the removal of a postmaster so clearly involved an inferior office that congressional limitation on his removal did not violate legitimate executive authority. 272 U.S. at $187,241$.

${ }^{117}$ The Court refused to decide whether its reasoning led to such a result, although it conceded that it was "difficult to avoid a negative answer." 272 U.S. at 162. 
vests the appointment power solely in the executive branch.

The Myers Court's attempt to classify the extent of the President's removal power in terms of the appointment process did not last long. Nine years later, in Humphrey's Executor $v$. United States, ${ }^{118}$ the Supreme Court disapproved Myers' broad proposition that no congressional restriction on the President's removal power would be constitutional for officials appointed with the advice and the consent of the Senate. Faced with the President's removal of a Federal Trade Commissioner, the Court held that the President's power to remove such a quasi-legislative and quasi-judicial officer can be restricted by Congress. It limited the Myers holding to purely executive officers, but stated that such an officer is "inherently subject to the exclusive and illimitable power of removable by the Chief Executive, whose subordinate and aid he is." 119 Humphrey's Executor leaves unsettled whether the appointment process remains the test for determining which executive officers are subject to an unrestrictable presidential power of removal. Clearly, however, at least at some level, the executive power of removal for executive officers remains so essential that it cannot constitutionally be limited. Even below that level, the assertions in Parsons and subsequent cases about the relationship of the power of removal to the efficient administration of government remain unquestioned in the federal courts.

The second line of cases denying judicial relief to government employees challenging removals or other adverse actions is based on a concern for legislative flexibility in creating executive offices. The Supreme Court has sought to protect the power of succeeding legislatures to reform the government structure by allowing the modification or abolition of executive positions. It thus enunciated the proposition that statutory terms of employment do not themselves create contract or property rights and therefore can be altered by a later statutory amendment.

The leading case supporting this proposition is Butler $v$. Pennsylvania. ${ }^{120}$ In Butler, the Court rejected a state official's

118295 U.S. 602 (1935).

${ }^{119} \mathrm{Id}$. at 627. Humphrey's Executor was followed in Wiener v. United States, 357 U.S. 349 (1958), which, while limiting the presidential power of removal over the War Claims Commission, a quasi-judicial body, supported the Myers doctrine of sole presidential power of removal over purely executive officers.

12051 U.S. (10 How.) 402 (1850). 
claim that he was entitled to the statutory per diem amount specified at the time of his appointment rather than the lower amount provided by a statutory amendment passed during his term of office. The Court noted that if the official's right to a salary were considered a contract, "the government would have to become one great pension establishment on which to quarter a host of sinecures."121 The Butler case was followed by Crenshaw $v$. United States, ${ }^{122}$ in which the Court rejected a claim by a cadet midshipman that he was entitled to an appointment as a midshipman under the statute as it existed at the time of his enlistment despite a legislative reversal of policy during his time as a cadet. The Court upheld the cadet's discharge, rejecting his claim of contract rights and stating rather broadly: "He enjoys a privilege revocable by the sovereignty at will; and one legislature cannot deprive its successor of the power of revocation."123

The Supreme Court has sought subsequently, though not altogether successfully, to distinguish between legislative creation of terms of employment for government officials, which a subsequent legislature can change at will, and its creation of a government contractual obligation with an employee, which cannot constitutionally be altered by later legislative action. ${ }^{124}$ In Hall $v$. Wisconsin, ${ }^{125}$ the Court held that once legislation had authorized the hiring of a commissioner to make a geological survey under a written contract with the governor, the surveyor's contract could not be terminated by the repeal of the authorizing legislation. The Court emphasized that the legislature had specifically required a written contract with the surveyor, thus distinguishing the case from an attempt to abolish a public office. "It would

${ }^{121}$ Id. at 416. The Court added:

[T]he appointment to and the tenure of an office created for the public use, and the regulation of the salary affixed to such an office, do not fall within the [contract clause]; do not come within the import of the term contracts, or, in other words, the vested, private personal rights thereby intended to be protected. They are functions appropriate to that class of powers and obligations by which governments are enabled, and are called upon, to foster and promote the general good; functions, therefore, which governments cannot be presumed to have surrendered, if indeed they can under any circumstances be justified in surrendering them.

Id. at 417 .

122134 U.S. 99 (1890).

${ }^{123}$ Id. at 108. Cf. Higginbotham v. City of Baton Rouge, 306 U.S. 535 (1939).

${ }^{124}$ Compare Dodge v. Board of Educ., 302 U.S. 74 (1937), and Phelps v. Board of Educ., 300 U.S. 319 (1937), with Indiana ex rel. Anderson v. Brand, 303 U.S. 95 (1938). See also id. at 113-17 (Black, J., dissenting).

125103 U.S. 5 (1880). 
be a novel and startling doctrine ... that the government might discard ... [employees] at pleasure, because their respective employments were public offices, and hence without the protection of contract rights." ${ }^{126}$ In Indiana ex rel. Anderson $v$. Brand, ${ }^{127}$ the Court held unconstitutional Indiana's repeal of the teacher tenure law under which the petitioner had gained tenure. The Court found that the tenure law specifically created an indefinite contractual right of employment once the necessary length of service was completed, and that such a contract could not be terminated by a subsequent legislative decision to abolish the policy of tenure. The Court cautioned, however, that there is a limit to the government's ability to bind itself contractually. At some point, an attempt to limit by contract a future government's flexibility in changing terms of employment would violate public policy. The Court emphasized that in this case the government had not ceded its necessary flexibility, because the grounds for the discharge of tenured teachers-incompetence, a justifiable decrease in the number of teaching positions, or "other good and just cause"-were very broad indeed. ${ }^{128}$

Thus even the cases finding the creation of constitutionally protected contract rights recognize the importance of legislative flexibility to modify employment terms or discharge unneeded employees. Preventing one legislature from irreparably binding succeeding generations through the creation of executive positions allows the removals and revisions essential to the continuing reformation of the government service.

The third line of cases in which the Court has refused to review removals of government employees is based on the notion that these questions are administrative and not judicial in nature. In Keim v. United States, ${ }^{129}$ the Secretary of the Interior had discharged a civil servant on the ground of inefficiency. The employee objected that retained employees had not been shown to possess better capacity to do their jobs and that he had in fact performed his job efficiently. The Court, citing Hennen and Parsons as upholding the inherent power of removal, ${ }^{130}$ went beyond those cases to say that such a dismissal is beyond the review of the courts.

${ }^{126} I d$. at 10.

127303 U.S. 95 (1938).

${ }^{128} \mathrm{Id}$. at $107-08$.

129177 U.S. 290 (1900).

${ }^{130} I d$. at 294. 
[I]f courts should not be called upon to supervise the results of a civil service examination equally inappropriate would be an investigation of the actual work done by the various clerks, in comparison of one with another as to competency, attention to duty, etc. These are matters peculiarly within the province of those who are in charge of and superintending the departments, and until Congress by some special and direct legislation makes provision to the contrary, we are clear that they must be settled by those administrative officers. ${ }^{131}$

Most of the development of the Keim doctrine has occurred in lower courts. For example, in United States ex rel. Taylor $v$. Taft, ${ }^{132}$ the Supreme Court of the District of Columbia held that it had no jurisdiction to review the Secretary of War's dismissal of a clerk who had written a critical article about the President. The employee objected that the procedure mandated by President McKinley's Executive Order ${ }^{133}$ had not been followed, but the Court rejected any judicial role in reviewing the basis of executive removals, stating that "[a]ny other conclusion would encourage inefficiency and incompetency in office, and be fruitful of insubordination." 134

\section{From Bailey v. Richardson to Board of Regents 1 . Roth}

Given the unbroken line of cases upholding the importance of the removal power to the executive, the essential nature of legislative flexibility in creating and altering the terms of government employment, and the administrative nature of the questions underlying employee dismissals, one can understand Judge Prettyman's surprise at the boldness of the contention

${ }^{131}$ Id. at $295-96$.

13224 App. D.C. 95 (Sup. Ct. 1904), appeal dismissed, 203 U.S. 461 (1906).

${ }^{133}$ See note 70 supra \& accompanying text.

${ }_{134} 24$ App. D.C. at 99. Lower federal courts consistently rejected the notion that the Executive Orders limiting the removal power or the Lloyd-LaFollette Act of 1912 gave any power to the courts to review the evidence or the substance of the reasons for employee dismissal. Despite employees' allegations of innocence, the courts routinely rejected their claims as failing to state a cause of action. See, e.g., Levy v. Woods, 171 F.2d 145 (D.C. Cir. 1948); Culligan v. United States, 107 Ct. Cl. 222 (1946), cert. denied, 330 U.S. 848 (1947); Levine v. Farley, 107 F.2d 186 (D.C. Cir. 1939), cert. denied, 308 U.S. 622 (1940); Golding v. United States, 78 Ct. Cl. 682, cert. denied, 292 U.S. 643 (1934); Page v. Moffett, 85 F. 38 (C.C.D.N.J. 1898). For a discussion of whether the fundamental proposition of Keim-that the question of employee competence is not a proper judicial question-remains valid, see Part III infra. 
made in Bailey $v$. Richardson ${ }^{\mathbf{1 3 5}}$ that the Constitution required a certain procedure before Ms. Bailey could be discharged from government employment for being disloyal to the United States. She challenged her dismissal on a number of statutory grounds, but did not herself raise the constitutional issue; that issue was raised by disagreement within the panel of the court of appeals. ${ }^{136}$ Judge Prettyman referred to the unbroken 160year history of refusing to grant judicial hearings to government employees and to the Civil Service Act itself, which specifically denied the need for a hearing. If a hearing were to be constitutionally required for Ms. Bailey, he reasoned, the entire history of cases would have to be overruled, and the LloydLaFollette Act itself declared unconstitutional. ${ }^{137}$ Although Judge Prettyman referred to the Holmes concept of privilege, ${ }^{138}$ the history of the federal cases was the primary basis for his rejection of any constitutional claim.

Yet Judge Edgerton, dissenting in Bailey, emphasized that he did not seek to reopen the history of employment dismissal cases, for this, he said, was not a normal dismissal.

Most dismissals, including among others dismissals for colorless or undisclosed reasons and dismissals for incompetence, are plainly not punitive. They do not require a judicial trial or even a full administrative hearing. They are within the authority of the executive. . . . It does not follows [sic] that . . . all executive dismissals are constitutional. ${ }^{139}$

Here Ms. Bailey was discharged for exercising what she claimed to be her constitutional rights of free speech and assembly and was punished with the most serious label of disloyalty. ${ }^{140}$ One

${ }^{135} 182$ F.2d 46 (D.C. Cir. 1950), aff'd per curiam by an equally dizided Court, 341 U.S. 918 (1951).

${ }^{136} \mathrm{Id}$. at 55 .

${ }^{137}$ Id. at 56-58.

${ }^{138} \mathrm{Id}$. at 59.

${ }^{139} \mathrm{Id}$. at 69.

${ }^{140}$ Judge Edgerton argued that Ms. Bailey's discharge for disloyalty was, unlike a normal dismissal, a form of punishment. This argument was based on United States v. Lovett, 328 U.S. 303 (1946), in which the Supreme Court struck down as an unconstitutional bill of attainder a congressional specification not to pay the salary of three named individuals, thus permanently barring them from public employment. The Court said in Lovett that " $[\mathrm{t}]$ his permanent proscription from any opportunity to serve the Government is punishment, and of a most severe type." Id. at 316 . But because Ms. Bailey was subject only to removal, and not to a permanent bar to future employment (a 
need not question the government's ability to discharge employees routinely without a hearing, he argued, in order to believe it appropriate to place limits upon the government's ability to discharge employees for exercising constitutional rights. Although Judge Edgerton's attempt in Bailey to create some protection for the exercise of constitutional rights in government employment was unsuccessful, it formed the basis for a series of succeeding cases, beginning with Wieman $v$. Updegraff, ${ }^{141}$ that began to protect those rights.

The Supreme Court's first limitation on the executive power of removal, imposed in Wieman, was a narrow one. Two factors combined to justify the Court's striking down a state attempt to discharge individuals solely for innocent membership in certain organizations: The activity causing the removal was encompassed by the constitutionally protected freedom of association $^{\mathbf{1 4 2}}$ and the infringement of the constitutionally protected freedom was not necessary to achieve legitimate government objectives, but was "an assertion of arbitrary power."143 This concept-that the government cannot dismiss employees for reasons not relevant to their employment, under circumstances where the activity objected to is constitutionally protected-is a very limited restriction on the executive power of removal, and subsequent cases have made clear that both these factors must be found before an executive removal will be invalidated. ${ }^{144}$ The legitimacy of the right of removal, as articulated in Parsons $^{145}$ and Myers $^{146}$ depends upon the needs of the executive to manage his work force. Requiring that serving these needs be shown before constitutional liberties of employees can be limited

limited bar was attempted but struck down as unauthorized by statute), Lovelt was found distinguishable by the majority. See 182 F.2d at 55 .

141344 U.S. 183 (1952).

${ }^{142}$ See, e.g., Cole v. Richardson, 405 U.S. 676, 680 (1972); Speiser v. Randall, 357 U.S. 513,519 (1958).

143344 U.S. at 191. Thus, the broad statement in Wieman that "constitutional protection does extend to the public servant whose exclusion pursuant to a statute is patently arbitrary or discriminatory," id. at 192, widely hailed as the end of the concept of privilege, is limited in its context to an exclusion that raises serious constitutional questions of freedom of association without adequate justification in terms of governmental objectives.

${ }^{144}$ See, e.g., Pickering v. Board of Educ., 391 U.S. 563 (1968); Slochower v. Board of Educ., 350 U.S. 551 (1956).

145 Parsons v. United States, 167 U.S. 324 (1897). See text accompanying notes 100-02 supra. supra.

${ }^{146}$ Myers v. United States, 272 U.S. 52 (1926). See text accompanying notes 106-17 
seems a modest protection of constitutional rights. Moreover, nothing in such a doctrine violates Keim $v$. United States ${ }^{\mathbf{1 4 7}}$ by turning the issue of an employee's competence into a judicial rather than an administrative question. Wieman is a substantive limit on the removal power, not a procedural requirement for the legitimate exercise of that power. ${ }^{148}$

The limited nature of the incursion on executive power made in Wieman is demonstrated by subsequent cases that have limited the executive removal power because of infringement of constitutional rights. In Slochower $v$. Board of Education, ${ }^{149}$ the Supreme Court struck down as arbitrary a New York City charter provision mandating the termination of a city employee who invoked the fifth amendment. Having found that this prohibition covered every city employee who invoked the fifth amendment, regardless of reasons, the Court went on to note that the invocation of the fifth amendment in the instant case was not relevant to the job performance of the individual: "The State has broad powers in the selection and discharge of its employees, and it may be that proper inquiry would show Slochower's continued employment to be inconsistent with a real interest of the State. But there has been no such inquiry here."150

Similarly, in Pickering $v$. Board of Education,,$^{151}$ the Court invalidated the dismissal of a high school teacher for writing a letter to the local newspaper criticizing the school board's handling of a bond issue. While stating that the teacher could not constitutionally be compelled to relinquish his first amendment rights as a public employee, the Court went on to say:

147177 U.S. 290 (1900).

148 The Court momentarily seemed to suggest otherwise in Connell v. Higginbotham, 403 U.S. 207 (1971), when it said that the use of an impermissible oath "falls within the ambit of decisions of this Court proscribing summary dismissal from public employment without hearing or inquiry required by due process." Id. at 208. Yet the following year, in Cole v. Richardson, 405 U.S. 676 (1972), the Court made clear that Connell did not mean that a hearing was required in every discharge case:

All of the cases in this Court that require a hearing before discharge for failure to take an oath involved impermissible oaths. ... [In Connell] the Court held only that the mere refusal to take the particular oath was not a constitutionally permissible basis for termination. In the circumstances . . . only by holding a hearing, showing evidence of disloyalty, and allowing the employee an opportunity to respond might the State develop a permissible basis for concluding that the employee was to be discharged.

Id. at 686 .

149350 U.S. 551 (1956).

150 Id. at 559.

151391 U.S. 563 (1968). 
At the same time it cannot be gainsaid that the State has interests as an employer in regulating the speech of its employees that differ significantly from those it possesses in connection with regulation of the speech of the citizenry in general. The problem in any case is to arrive at a balance between the interests of the teacher, as a citizen, in commenting upon matters of public concern and the interest of the State, as an employer, in promoting the efficiency of the public services it performs through its employees. ${ }^{152}$

The Court pointed out that Pickering did not involve the maintaining of discipline by an immediate superior, the harmony among co-workers, or the relationship of trust and confidence necessary to the proper functioning of the school. Nor was it a case in which the teacher's statements impeded his ability to perform his job or called into question his ability to do so. ${ }^{153}$ Like Wieman, Pickering presented both the exercise of a constitutional right and the discharge of an individual for that exercise when the discharge was irrelevant to his performance of his duties.

The fact of relevance distinguishes Civil Service Commission v. Letter Carriers ${ }^{154}$ from Pickering; in Letter Carriers, the Court reaffirmed its position in United Public Workers v. Mitchell ${ }^{155}$ and upheld the constitutionality of the prohibition against federal employees' taking "an active part in political management or in political campaigns." ${ }^{156}$ The Court noted that the restriction on political freedom was part of the legitimate government effort to improve the efficiency and effectiveness of government service. ${ }^{157}$

In 1961, the Supreme Court made clear that no specific procedures were required in a discharge case that did not involve the exercise of constitutional rights. In Cafeteria $E$ Restaurant Workers Local 473 v. McElroy, ${ }^{158}$ Rachel Brawner, an employee who worked in a government facility for a government contractor, was excluded from her job by the government's summary determination that she was a security risk. The Court

\footnotetext{
${ }^{152} I d$. at 568.

${ }^{153} \mathrm{Id}$. at 573 n.5.

154413 U.S. 548 (1973).

155330 U.S. 75 (1947).

156413 U.S. at 550.

${ }^{157} \mathrm{See}$ id. at $564-65$.

158367 U.S. 886 (1961).
} 
denied the employee's claim that the Constitution required a hearing prior to her denial of a security clearance. In language quoted frequently, the Court said:

The Fifth Amendment does not require a trial-type hearing in every conceivable case of government impairment of private interest. . . “ '[D]ue process,' unlike some legal rules, is not a technical conception with a fixed content unrelated to time, place and circumstances." It is "compounded of history, reason, the past course of decisions ...."

As these and other cases make clear, consideration of what procedures due process may require under any given set of circumstances must begin with a determination of the precise nature of the government function involved as well as of the private interest that has been affected by governmental action. ${ }^{159}$

The Court then turned to the nature of the governmental interest in question in the case at hand:

This case . . . involves the Federal Government's dispatch of its own internal affairs. The Court has consistently recognized that an interest closely analagous to Rachel Brawner's, the interest of a government employee in retaining his job, can be summarily denied. It has become a settled principle that government employment, in the absence of legislation, can be revoked at the will of the appointing officer. ${ }^{160}$

The Court went on to distinguish the claim for procedural due process from Wieman v. Updegraff:

But to acknowledge that there exist constitutional restraints upon state and federal governments in dealing with their employees is not to say that all such employees have a constitutional right to notice and a hearing before they can be removed. We may assume that Rachel Brawner could not constitutionally have been excluded from the Gun Factory if the announced grounds for her exclusion had been patently arbitrary or discriminatory . . . It does not follow, however, that she was entitled to notice and a hearing when the

${ }^{160} \mathrm{Id}$. at 896 (footnotes omitted). 
reason advanced for her exclusion was, as here, entirely rational. ... ${ }^{\mathbf{1 6 1}}$

The Court noted that the denial of a security pass could mean simply that Miss Brawner was garrulous or careless with her badge, and had itself no implication of disloyalty. ${ }^{162}$ The Court clearly implied that had it been alleged that the employee was garrulous, she would have had no right to a hearing to determine whether or not that charge was true, and, if true, whether it constituted sufficient grounds for dismissal. ${ }^{163}$

Thus the history of the Supreme Court's opinions prior to Board of Regents $v$. Roth, ${ }^{164}$ like that of the civil service reform movement prior to the Veterans' Preference Act of $1944,{ }^{165}$ is not based on any attempt to make the superior "prove" his case against an employee prior to dismissal. The Court and the Congress agreed that the termination decision was for the executive to make unless the removal was for an impermissible reason, such as the exercise of constitutional rights or the nature of the employee's political beliefs. An allegation that the grounds for removal were mistaken, would not, by itself, necessitate a trialtype hearing.

Beginning with the Veterans' Preference Act of 1944, and confirmed by President Kennedy's Executive Order of 1962, ${ }^{166}$ the Congress and the President began to question the wisdom of relying on executive discretion in employee discharges. Job security in the civil service, a concept rejected by the Decision of 1789 but implemented before Jackson's expansion of the spoils system, has reappeared in government service as a consequence of required evidentiary hearings prior to discharge. Like the Tenure of Office Act of 1867, these changes attempt to limit

${ }^{161}$ Id. at 898.

162 Id. at 899 . It may be, however, that Ms. Brawner now would have a protected liberty interest under Board of Regents v. Roth, 408 U.S. 564 (1972). See text accompanying notes 212-15 infra.

${ }^{163}$ Even the four dissenters did not say that a judicial trial would be necessary but only that she was entitled to some process. 367 U.S. at 900 . At least in the cases where a security risk designation means something very odious, they said, the employee is entitled to be told in detail the reasons for her denial so that she can defend her innocence "in order to show, perhaps, that the true reason for deprivation was one forbidden by the Constitution." Id. at 901 .

164408 U.S. 546 (1972).

${ }^{165}$ Act of June 27, 1944, ch. 287, 58 Stat. 387. See text accompanying notes 53-82 supra.

${ }^{166}$ Exec. Order No. 10,987, 3 C.F.R. 519 (Comp. 1959-1963), 5 U.S.C. $§ 7501$ (1970). 
what appears to be excessive executive authority over his appointees. If the executive or the legislature were to decide to modify these recent efforts to establish a judicial process for determining employee competence, the question would arise whether they can still do so-whether, in other words, the present system is now constitutionally mandated under Board of Regents $v$. Roth, ${ }^{167}$ Perry v. Sindermann, ${ }^{168}$ and Arnett v. Kennedy. ${ }^{169}$

\section{RotH, SINDERMANN, AND ARNETT}

\section{A. What the Cases Hold}

Roth and Sindermann brought an end to the Supreme Court's consistent rejection of a judicial role in establishing minimum procedures to be followed before an employee dismissal. So sudden was the break with the past that no opinion in either case-and only one of the five opinions in Arnett $v$. Kennedy that followed them ${ }^{170}$-even bothered to cite the history of cases dealing with government employee removals. Perhaps the omission in Roth and Sindermann of references to the earlier line of cases stems from the fact that both cases dealt with state, not federal, employee actions, although some of the prior cases dealt with state dismissals as well. ${ }^{171}$ In any event, the results of Roth and Sindermann were so sweeping that most of the Court in Arnett treated the history of consideration of the employeeremoval issue as if it began with these cases. It is therefore important to determine the precise effect these cases have had on the capacity of government to determine the procedures and the grounds for removing its employees.

Both Roth and Sindermann concerned teachers whose contracts were not renewed by their boards of regents. Both teachers alleged that the reason for their not being retained was their exercise of constitutionally protected free speech. In Roth, the Court did not reach the free speech question because the district court had stayed proceedings on that issue; ${ }^{172}$ in

167408 U.S. 564 (1972).

168408 U.S. 593 (1972).

169416 U.S. 134 (1974).

${ }^{170} \mathrm{Id}$. at $181-82$ (White, J., concurring in part \& dissenting in part).

${ }^{171}$ See, e.g., Taylor \& Marshall v. Beckham (No. 1), 178 U.S. 548 (1900); Williams v. North Carolina, 169 U.S. 586 (1898); Butler v. Pennsylvania, 51 U.S. (10 How.) 402 (1850). Arnett dealt with a dismissal of a federal employee.

172408 U.S. at 574. 
Sindermann, the Court found a bona fide constitutional claim, and reversed the district court's grant of summary judgment on that issue. ${ }^{173}$ As they were presented, therefore, Roth and Sindermann could readily have been decided on the familiar ground of the post-Wieman cases, notably Pickering $\%$. Board of Education, ${ }^{174}$ that constitutionally protected speech is an impermissible ground for discharge (and presumably for nonrenewal) if the curb on protected activity is unnecessary for ensuring effective job performance.

The Roth Court addressed the issues more broadly, however, because it seemed to reject (or at least ignore) the previously accepted judicial deference given the executive's decisions to terminate its employees, adopting instead an attitude suspicious of government bureaucracy and its motives. The widespread and increasing uneasiness about the power and influence of the government bureaucracy ${ }^{175}$ seemed to demand an emphasis on individual rights to check and control that bureaucracy's power. By shifting the focus of concern from the government's needs to those of the individual, the Court attempted to adjust the balance between public and private interests. Nowhere is this shift in emphasis more apparent than in Justice Marshall's dissent in Roth, where he said that, in his view, "every citizen who applies for a government job is entitled to it unless the government can establish some reason for denying the employment." 176 But establishing the proper balance between the rights of the individual and the needs of the government is peculiarly difficult in the context of public employment. Too great an emphasis on the protection of public employees against government dismissals may reduce the caliber of government employees and thus weaken the ability of government to function intelligently. A bureaucracy so constituted may create a serious threat to the rights of the public at large. The more entrenched the government work force, the less likely it becomes that the public can receive fair and effective treatment from its government. It is because of these kinds of concerns that the Court had in the past

173408 U.S. at 598.

174391 U.S. 563 (1968).

${ }^{175}$ See Richardson v. Perales, 402 U.S. 389, 413 (1971) (Douglas, J., dissenting); Freedman, Crisis and Legitimacy in the Administrative Process, 27 Sran. L. Rev. 1041, 1064-68 (1975); Friendly, "Some Kind of Hearing," 123 U. PA. L. REv. 1267, 1279-80 (1975). See also text accompanying note 2 supra.

176408 U.S. at 588 . 
consistently upheld executive and legislative flexibility in enforcing standards of performance for government employees. Thus the Court's decision in Roth not only effected a balance between an individual employee and his organizational employer, but also, as Madison predicted in $1789,{ }^{177}$ affected the balance between the government and its citizens.

In formulating this new position on government employee removals, the Roth Court first attempted to circumscribe its application. Since every government action affects individuals' rights, the Court had to adopt some basis for deciding the type of cases in which the developing notion of procedural due process $^{178}$ is applicable. The district court in Roth held that the requirement of affording individuals procedural due process applies to any case of governmental action, once the balancing of the governmental and the individual interests is determined to favor the individual. ${ }^{179}$ The Supreme Court rejected such a broad notion, stating that the requirement of procedural due process applies only when an individual's interest in "property" or "liberty," as protected by the fourteenth amendment, is infringed by the government action. ${ }^{180}$ But the Court's attempt at limitation proved to be less important than the expansion of the procedural due process protection engendered by its definitions of protected "property" and "liberty." Both these definitions may indicate a complete reversal of the prior 140 years of deference to executive discretion in employee dismissals in favor of the protection of individual rights.

The Roth Court said that one would have a "property interest" in a benefit if he had

more than an abstract need or desire for it. He must have more than a unilateral expectation of it. He must, instead, have a legitimate claim of entitlement to it. It is a purpose of the ancient institution of property to protect those claims upon which people rely in their daily lives, reliance that must not be arbitrarily undermined. It is a purpose of the constitutional right to a hearing to

${ }^{177}$ See text accompanying note 25 supra.

${ }^{178}$ E.g., Goldberg v. Kelly, 397 U.S. 254, 261 (1970) (welfare); Sniadach v. Family Fin. Corp., 395 U.S. 337 (1969) (garnishment). Morrisey v. Brewer, 408 U.S. 471 (1972), concerning parole revocation, was decided the same day as Roth and Sindermann. 179310 F. Supp. $972,977-79$ (W.D. Wis. 1970).

${ }^{180} 408$ U.S. at 571. 
provide an opportunity for a person to vindicate those claims. ${ }^{181}$

The plaintiff in Roth had "absolutely no possible claim of entitlement to re-employment," 182 and thus no protected property interest. The plaintiff in Sindermann, however, alleged the existence of a de facto tenure system, and the Court held that this system, if proved, would create a property interest protected by the fourteenth amendment. ${ }^{183}$ One could reason from Sindermann that if the plaintiff there could establish an adequate property interest because of a de facto tenure system, then any government employee whose tenure was protected by civil service would have "a legitimate claim of entitlement" to his job and would thus be protected by the fourteenth amendment's requirement of procedural due process before he could be deprived of that property. The concept of property in office, opposed by proponents of the spoils system and of civil service reform alike, ${ }^{184}$ would thus be created as a constitutional right simply by the adoption of the Civil Service statute. And so the Court held in Arnett $v$. Kennedy. ${ }^{185}$

In Arnett, the plaintiff was a career civil servant who could be removed only for "such cause as will promote the efficiency of the service," pursuant to the Lloyd-LaFollette Act, ${ }^{186}$ Executive Order 11491,187 and regulations thereunder. ${ }^{188} \mathrm{He}$ was discharged for, among other reasons, falsely charging a supervisor with attempted bribery. ${ }^{189}$ Kennedy asserted that he had a constitutionally protected property interest in his job under Roth, and that the procedures provided by the Civil Service statute and the Executive Order-notice and right to reply prior to dismissal and a full trial-type hearing only on appeal after dismissal-were

181 Id. at 577 .

182 Id. at 578 .

183408 U.S. at 602-03.

${ }^{184}$ See text accompanying notes 61-63 supra.

185416 U.S. 134 (1974).

1865 U.S.C. $\$ 7501$ (1970).

1873 C.F.R. 262 (1973), 5 U.S.C. $\$ 7301$ (1970).

${ }^{188}$ E.g., 5 C.F.R. $\S \S 735.201$ a, .209 (1973) (Civil Service); 45 C.F.R. $\$ \S 1015.735$ 1, -24 (1973) (Office of Economic Opportunity).

189416 U.S. at 137. Regulations of the Office of Economic Opportunity, by which Kennedy was employed, and of the Civil Service make dishonesty and undermining public confidence in the agency cause for dismissal. See 5 C.F.R. \$\$ 735.201a(f), .209 (1973) (Civil Service); 45 C.F.R. $\S \S 1015.735-1$, -24 (1973) (Office of Economic Opportunity). 
unconstitutional. ${ }^{190} \mathrm{He}$ argued that he had a right to a trial-type hearing before an impartial hearing officer prior to his removal from government employment. ${ }^{191}$

Although the five opinions in Arnett represent three, or possibly four, different views about the kinds of procedures constitutionally mandated in employee dismissals, ${ }^{192}$ six of the nine Justices agreed, and the Court thus held, that under Roth civil servants are given a property interest in their jobs by the LloydLaFollette Act, a property interest that cannot be taken away without constitutionally imposed procedures. ${ }^{193}$ Justices Powell, White, and Marshall argued that while it is a legislative decision whether or not to confer a property interest in a job, once the legislature does so, the procedure necessary to safeguard that interest is a matter of constitutional mandate, not legislative choice. They found that the legislature did intend to confer a property interest by limiting discharge to "such cause as will promote the efficiency of the service," and thus rejected the notion that the further legislative proviso that "no examination of witnesses nor any trial or hearing shall be required" settled the question of what procedure is constitutionally required to protect the property interest created.

Only Justice Rehnquist, writing for the plurality of himself, the Chief Justice, and Justice Stewart (who had written the majority opinions in Roth and Sindermann), argued against the existence of a constitutionally protected property interest. ${ }^{194} \mathrm{He}$

190416 U.S. at $138-39$.

191 Id. at 137.

192 See text accompanying notes 221-26 infra.

193416 U.S. at 167 (Powell, J., concurring in part); id. at 185 (White, J., concurring in part \& dissenting in part); id. at 211 (Marshall, J., dissenting). Arnett was not the first case that suggested such a result. In Reagan v. United States, 182 U.S. 419 (1901), the Court rejected the notion that the power of the United States judges in the Indian Territory to remove commissioners had been limited by statute, and went on to speculate about the consequences if there had been specific limitations of the removal power:

If there were, then the rule would apply that where causes of removal are specified by constitution or statute, as also where the term of office is for a fixed period, notice and hearing are essential. If there were not, the appointing power could remove at pleasure or for such cause as it deemed sufficient.

Id. at 425 . But subsequent decisions consistently rejected such a view. In Cafeteria \& Restaurant Workers Local 473 v. McElroy, 367 U.S. 886 (1961), the Court reaffirmed the "principle that government employment, in the absence of legislation, can be revoked at the will of the appointing officer." Id. at 896. The Court in Roth and Sindermann took the phrase "in absence of legislation" to mean more than merely that the government must follow legislation if legislation exists, but to mean that if legislation exists, the Constitution itself provides procedural protection for the individual.

194416 U.S. at 151-52 (plurality opinion). 
reasoned that since the Lloyd-LaFollette Act provides in the same section that removal shall be for cause and that the proper procedure is notice and the right to reply, without trial or hearing, ${ }^{195}$ the plaintiff was "entitled" in the Roth sense to no more than the statute provided him: cause determined by the procedure specified in the statute. ${ }^{196}$

To conclude otherwise would require us to hold that although Congress chose to enact what was essentially a legislative compromise, and with unmistakable clarity granted governmental employees security against being dismissed without "cause," but refused to accord them a full adversary hearing for the determination of "cause," it was constitutionally disabled from making such a choice. ... Neither the language of the Due Process Clause of the Fifth Amendment nor our cases construing it require any such hobbling restrictions on legislative authority in this area. ${ }^{197}$

Justice Rehnquist's opinion has been criticised as an erroneous, "positivist" view of Roth, a view that would destroy the newly expanded concept of constitutionally mandated procedural due process. ${ }^{198}$ A Roth property right would be worthless, it is argued, if the legislature could establish only a minimum procedure-or no procedure at all-before denying that right. Although the Rehnquist opinion could be read so broadly as to undermine completely the Roth entitlement concept (and Justice Marshall in dissent read it this way), ${ }^{199}$ it could also be read to reflect only the situation the Court faced in Arnett, a civil service discharge. The history of the creation of the combined causeand-no-hearing provisions in the Lloyd-LaFollette Act, as shown earlier, ${ }^{200}$ demonstrates that those provisions were designed not merely as an attempt to establish a procedure for determining the existence of cause, but as a legislative effort to designate the meaning of "cause." Under the Lloyd-LaFollette Act, an employee's job security is subject to his supervisor's discretion to discharge him if the supervisor has a bona fide reason to do so,

\footnotetext{
${ }^{195} 5$ U.S.C. $\$ 7501$ (a), (b) (1970).

196416 U.S. at 152.

197 Id. at 154.

${ }^{198}$ See, e.g., Tribe, Structural Due Process, 10 Harv. Civ. Rights-Civ. Lib. L. Rev. 269, 277 (1975). But cf. The Supreme Court, 1973 Term, 88 Harv. L. Rev. 41,87 (1974).

199416 U.S. at 211 (Marshall, J., dissenting).

${ }^{200}$ See text accompanying notes 78-81 supra.
} 
and the supervisor's reason is not subject to second guessing by a third party without proof of an impermissible ground for the discharge, such as political allegiance. An employee's "entitlement" before his discharge is not an entitlement to "cause" as determined by an impartial hearing, but only to a good faith reason given him by his supervisor. Such a reliance on executive discretion was not questioned until the enactment of the Veterans' Preference Act of $1944^{201}$ (which did not apply to Kennedy). ${ }^{202}$ Thus Justice Rehnquist could have been saying simply that Congress did not intend in the Lloyd-LaFollette Act to create a property interest in the sense the six Justices suggested, since one can grasp the meaning of the substantive entitlement only by reference to the procedure involved.

Not only is the "majority" reading of the legislative history of the Lloyd-LaFollette Act questionable, its clear finding of a property right created by the Act runs counter to the entire history of removal cases. Justice White, the only one who bothered even to mention that history, is unconvincing in his attempt to distinguish Hennen, Crenshaw, Parsons, and Keim on the ground that they arose before the civil service system restricted the executive's power to remove employees. ${ }^{203}$ The plaintiffs in these earlier cases, other than Hennen, ${ }^{204}$ would appear to have had what Roth would define as a claim of entitlement to their jobs. The district attorney in Parsons ${ }^{\mathbf{2 0 5}}$ had a four-year appointment to his post; the cadet midshipman in Crenshaw $^{206}$ was given a statutory right to appointment if the specified steps were successfully completed; the plaintiff in $\mathrm{Keim}^{207}$ was a civil servant, protected by the 1897 McKinley Executive Order ${ }^{208}$ which required, in words similar to the LloydLaFollette Act, that removal be for cause. Similarly, the plaintiff in Shurtleff ${ }^{209}$ could be removed "for inefficiency, neglect of duty or malfeasance in office." 210 If the plaintiff in Arnett had a property interest in his job, all these plaintiffs did as well. Yet the

${ }^{201}$ Ch. 287, 58 Stat. 387 (codified in scattered sections of 5 U.S.C.).

${ }^{202}$ See text accompanying notes 83-89 supra.

203416 U.S. at 181-82 (White, J., concurring in part \& dissenting in part).

${ }^{204}$ Ex parte Hennen, 38 U.S. (I3 Pet.) 230 (1839).

205 Parsons v. United States, 167 U.S. 324 (1897).

${ }^{206}$ Crenshaw v. United States, 134 U.S. 99 (1890).

${ }^{207}$ Keim v. United States, 177 U.S. 290 (1900).

${ }^{208}$ See text accompanying note 70 supra.

${ }^{209}$ Shurtleff v. United States, 189 U.S. 311 (1903).

${ }^{210} \mathrm{Id}$. at 313 . 
reasons these opinions cited for upholding the presidential power of removal ${ }^{211}$ went unmentioned in Arnett, as the Court looked only to Roth to sustain a concept of property in office.

Roth's definition of "liberty" may be an even broader reversal of the history of the removal cases than its definition of "property." Every government employee, whether or not a civil servant, is protected against infringement of liberty interests, while only those with government-created rights have protected property interests. ${ }^{212}$ The Roth Court seems to have adopted an expansive interpretation of "liberty" that encompasses far more than the exercise of constitutionally protected rights: ${ }^{213}$

In a Constitution for a free people, there can be no doubt that the meaning of "liberty" must be broad indeed....

There might be cases in which a State refused to re-employ a person under such circumstances that interests in liberty would be implicated. But this is not such a case.

The State, in declining to rehire the respondent, did not make any charge against him that might seriously damage his standing and associations in his community. It did not base the nonrenewal of his contract on a charge, for example, that he had been guilty of dishonesty, or immorality. Had it done so, this would be a different case. For "[w]here a person's good name, reputation, honor, or integrity is at stake because of what the government is doing to him, notice and an opportunity to be heard are essential." ...

Similarly, there is no suggestion that the State, in declining to re-employ the respondent, imposed on him a stigma or other disability that foreclosed his freedom to take advantage of other employment opportunities. The State, for example, did not invoke any regulations

${ }^{211}$ See text accompanying notes 100-05, 122-23, 129-31 supra.

${ }^{212}$ Perry v. Sindermann, 408 U.S. 593, 599-603 (1972); Board of Regents v. Roth, 408 U.S. 564, $572-79$ (1972).

213408 U.S. at 573. The extension of liberty from the earlier concepts of constitutionally protected rights (see, e.g., Wieman v. Updegraff, 344 U.S. 183 (1952)) to broader notions of individual interests had already taken place a year earlier in Wisconsin v. Constantineau, 400 U.S. 433 (1971). The public posting of an individual's name as an alcoholic, however, which the Court held in Constantineau required a prior hearing, is a "badge of infamy" considerably more damaging than being discharged from employment for inefficiency. 
to bar the respondent from all other public employment in state universities. Had it done so, this, again, would be a different case. ${ }^{214}$

If the Court was suggesting that any government employee would have a right to a trial-type hearing if he were discharged for a reason affecting his good name, it would appear that such a hearing would be required whenever a reason is given for discharge. If the reason given were sufficient to justify the discharge, let alone to be considered sufficient "cause" for it, it would inevitably have an adverse effect on future employment possibilities and thus would encroach upon an employee's liberty interests. Surely a dismissal of an employee for inefficiency, as in Keim, "might seriously damage his standing and associations in the community." For those employees not protected from discharge by civil service requirements, the government would, of course, have the option of dismissing them without giving any reason, although it would be ironic if Roth, in its effort to broaden the protection of rights, had the consequence of denying non-civil servants the most basic element of fairness, notice of the reason for the action taken. The Court attempted to limit the impact of its definition of liberty by stating that mere proof that Roth's record of nonretention might make him somewhat less attractive to future employers would not amount to a deprivation of liberty. ${ }^{215}$ Yet Roth could mean that if a damaging reason were given for the action, the discharge would have to be justified to a third-party trier of fact.

If such a definition of "liberty" were established, Congress would be unable to prevent the judicialization of the government employer-employee relationship even if it sought to create an area of unreviewable supervisory judgment as a basis for dismissal of any government employee. No legislative action could limit the necessity for a hearing if "liberty" were at stake; an evidentiary trial would be necessary for every employee discharged for a damaging reason. At least in theory, however, Congress would retain the power to revise the procedures stemming from the Roth definition of property simply by eliminating all restrictions on the power of removal. Yet even that legislative option would be illusory. If Congress were forced to choose between repealing 
civil service, thereby giving employees no protection from removal at all, or retaining civil service with at least some protection from arbitrary removals, it would of necessity choose the latter option. In fact, under the Roth-Arnett concept of property, Congress may no longer have room to maneuver to balance employees' rights and executive flexibility, to find some middle ground between no protection at all and an evidentiary trial prior to removal. It could not, for example, require only notice and the right to reply before dismissal of civil servants, since that is all the Lloyd-LaFollette Act now requires, ${ }^{216}$ and six Justices found such a limitation inapplicable in Arnett." ${ }^{217}$ "The doctrine of the six Justices thus has the quite significant effect of forcing the legislature to choose between (a) a non-entitlement regime of unfettered official choice (as in Roth) and (b) substantive restrictions on official choice accompanied by whatever procedural rights due process prescribes." 218 The Court thus seems to have rejected the need for legislative flexibility in creating executive offices emphasized in the Butler-Crenshaw line of cases. ${ }^{219}$

The issue remains, however, whether the Court, in its efforts to protect individuals against arbitrary government action, has, by its interpretation of the due process clause of the Constitution, prohibited in government the system of executive discretion envisioned by the Decision of 1789 , carried forward through the spoils system and the civil service reform movement until recent times, and upheld by the courts for 140 years. The issue is not answered by the definitions of liberty and property, because the establishment of a protected interest is only the first step in the Roth-Arnett analysis. "Once it is determined that due process applies, the question remains what process is due."220 Perhaps the Court left itself (along with the President and Congress) room to protect the public against incompetence in government, as well as to protect employees against abuse of government power, when it dealt with the question of the process to be required once a property or liberty interest is found. Indeed, the Arnett Court seems to have left this vital question open, if only by

${ }^{216} 5$ U.S.C. $\$ 7501$ (1970).

217 Of course, to the extent that Arnett does not hold the Lloyd-LaFollette Act unconstitutional, such a balance may still be possible.

${ }^{218} \mathrm{~F}$. Michelman, Formal and Associational Aims in Procedural Due Process at n.26, 1975 (unpublished manuscript on file with the University of Pennsylvania Law Review). But see The Supreme Court, 1973 Term, 88 Harv. L. Rev. 41, 87 (1974).

${ }^{219}$ See text accompanying notes 120-28 supra.

${ }^{220}$ Morrisey v. Brewer, 408 U.S. 471,481 (1972). 
virtue of its inability to agree on the procedures constitutionally required prior to dismissing an employee.

Four opinions detail the Court's views on the procedures required prior to depriving an employee of his property interest in his job. The Rehnquist plurality opinion can be read to mean that no process is constitutionally required, but, as noted above, the opinion might be limited to the context of the LloydLaFollette Act. ${ }^{21}$ Justice Marshall, in dissent, writing for himself and Justices Douglas and Brennan, argued that the Constitution requires a full trial-type hearing before removal because the nature of the harm inflicted on the affected employee outweighs the government's interest in administrative convenience and efficiency. ${ }^{222}$ Justice White, in a separate opinion, argued that a full trial-type hearing is necessary at some stage in the proceeding, but that the legislative choice to provide it only after the dismissal is constitutionally permissible. ${ }^{223}$ Justice White thus found in effect that the procedure outlined by the LloydLaFollette Act, taken by itself, is unconstitutional, and that its modification by Executive Order $11491^{224}$ was constitutionally mandated. Finally, Justice Powell, writing for himself and Justice Blackmun, stated that the procedures should be determined by balancing the government's interest in being able to act expeditiously in removing an unsatisfactory employee (an interest which he found substantial) against the employee's interest in retaining his job pending an evidentiary hearing. ${ }^{225}$ Casting the deciding votes on the constitutionality of current civil service removal procedure, Justice Powell wrote: "On balance, I would conclude that a prior evidentiary hearing is not required and that the present statute and regulations comport with due process by providing a reasonable accommodation of the competing interests." 226 What Justice Powell intended by "comport with due process" is unclear. He could have meant that the present procedures are the constitutional minimum required, agreeing with the substance of Justice White's opinion. On the other hand, he could have meant that the present procedures are the constitutional maximum to which an employee is entitled and that

221416 U.S. 134, 151-55. See text accompanying notes 200-02 supra.

222416 U.S. at 217-27 (Marshall, J., dissenting).

${ }^{223} \mathrm{Id}$. at 185-86, 201-02 (White, J., concurring in part \& dissenting in part).

2243 C.F.R. 262 (1973), 5 U.S.C. § 7301 (1970).

225416 U.S. at 168-69 (Powell, J., concurring).

${ }^{226} \mathrm{Id}$. at 171 . 
somewhat less process would also be constitutionally permissible. The ambiguity in Justice Powell's concurrence thus leaves open the question whether some vitality remains in the pre-Roth emphasis on executive discretion in employee discharges.

The process required when a liberty interest is found is also unsettled after Arnett. Justice Rehnquist cited the Roth footnote that articulated the reason for a hearing on the infringement of a liberty interest in reputation: "The purpose of such notice and hearing is to provide the person an opportunity to clear his name. Once a person has cleared his name at a hearing, his employer, of course, may remain free to deny him future employment for other reasons.' "227 $\mathrm{He}$ interpreted the liberty interest as being offended only by "dismissal based upon an unsupported charge which could wrongfully injure the reputation of an employee" and found a hearing after dismissal "sufficient compliance" with due process requirements. ${ }^{228}$ Justice Marshall argued that a full trial-type hearing prior to dismissal is required where a liberty interest is involved. ${ }^{229}$ Justice White did not address the question, calling it an "entirely separate matter," 230 while Justice Powell said, characteristically: "I find the present statute comports with due process even with respect to appellee's liberty interest." 231

Given the conflicting opinions in Arnett as to the nature of the constitutionally prescribed minimum procedures in employee removal cases, the case establishes only that a discharge from public employment must, in most cases, be pursuant. to some constitutionally prescribed procedure. ${ }^{232}$ Most importantly, none of the cases decided to date have even raised the issue of the procedures required in the type of employee removal most essential to effective government administration: a discharge for inadequate job performance. Roth, Sindermann, and Arnett all involved employees discharged for acts of misconduct, indeed for public statements critical of the government's administration of

${ }^{227} I d$. at 157 n.22 (quoting Board of Regents v. Roth, 408 U.S. $564,573 \cdot$ n. 12 (1972)).

${ }^{228}$ Id. at 157.

${ }^{229}$ Id. at 217 (Marshall, J., dissenting).

${ }^{230} I d$. at 178 n.6 (White, J., concurring in part \& dissenting in part).

${ }^{231} I d$. at 171 n. 6 .

${ }^{232}$ At present, the normal procedure is an evidentiary hearing not only at the federal level but in state and local civil service systems as well. See, e.g.., N.Y. Crv. SERv. LAW \& 75 (McKinney 1973); CAL. Gov'T CodE §§ 11513 (West 1966), 19578 (West 1963). 
public programs. None of the employees involved was criticized for inadequate performance of his own work. ${ }^{233}$ Yet it is in the context of a discharge for incompetence that the prior judicial emphasis on the importance of removals to government administration becomes most persuasive. Moreover, in this context, the additional issue raised in Keim v. United States ${ }^{234}$ - whether an evidentiary hearing, judicial or administrative, is even an appropriate mechanism to review a discharge based on a supervisory evaluation of employee job performance-becomes crucial as well. In his concurrence in Arnett, Justice White hinted that some room might remain for deference to executive discretion in a discharge from government employment for incompetence:

A different case might be put, of course, if the termination were for reasons of pure inefficiency, assuming such a general reason could be given, in which case it would be at least arguable that a hearing would serve no useful purpose and that judgments of this kind are best left to the discretion of administrative officials. This is not such a case, however, since Kennedy was terminated on specific charges of misconduct. ${ }^{235}$

\section{B. The Requirements of Procedural Due Process in a Discharge for Inadequate Job Performance}

In my opinion, a government employee should not be entitled under Roth, Sindermann, and Arnett to an evidentiary trial prior or subsequent to a discharge based solely on inadequate job performance. The reasons for this conclusion stem from the crucial role of the removal process in the management of government, as emphasized in the Parsons-Myers line of cases, ${ }^{236}$ from the nature of the employee evaluation itself, as articulated in the Keim line of cases, ${ }^{237}$ and from the fact that an

${ }^{233}$ Moreover, like the plaintiff in Pickering v. Board of Educ., 391 U.S. 563 (1968), neither plaintiff in Roth or Sindermann directed his criticism "towards any person with whom appellant would normally be in contact in the course of his daily work as a teacher. Thus no question of maintaining either discipline by immediate supervisors or harmony among coworkers is presented here." Id. at 569-70. Although the plaintiff in Arnett did criticize his immediate supervisor, among others, his criticism charged criminal violations and thus, since the charges might be true, raised questions about the motives of the supervisor in commencing the discharge action.

234177 U.S. 290 (1900).

${ }^{235} 416$ U.S. at 186 (White, J., concurring in part \& dissenting in part).

${ }^{236}$ See text accompanying notes 100-119 supra.

${ }^{237}$ See text accompanying notes 129-34 supra. 
evidentiary trial is not necessary to protect the legitimate interests of the government employee against abuse of government power. ${ }^{238}$ This is not to say that a civil servant should be entitled to no procedural protections prior to a discharge for incompetence. There should be protections, but they should be based on the need to build fairness into the government's personnel evaluation procedures rather than on the model of a judicial trial.

\section{The Nature of the Governmental Interest}

In deciding what minimum procedures should be constitutionally required for employee dismissals, "consideration . . . must begin," as the Supreme Court said in Cafeteria $\&$ Restaurant Workers Local 473 ข. McElroy, "with a determination of the precise nature of the government function involved."239 The government, in discharging employees, exercises its power "as proprietor, to manage the internal operation"240 of the government. As Parsons and Myers emphasized, ${ }^{241}$ government as a proprietor differs from government as regulator or lawmaker for the general public because decisions about effective internal administration are executive in nature, and thus ought properly to be subject to executive control.

When government exercises its regulatory powers, that is, when it acts outwardly upon some aspect of society, its assertion that a procedure would impair governmental efficiency must be balanced against the public's need to restrain that efficiency in the interests of fairness. A government argument that its regulatory ability would be adversely affected by requiring a certain procedure implies that the procedure, if adopted, would involve more costly or time consuming administrative effort. In such a case, the Supreme Court has held that administrative efficiency must give way to individual rights:

A prior hearing always imposes some costs in time, effort, and expense, and it is often more efficient to dispense with the opportunity for such a hearing. But

${ }^{238}$ See text accompanying notes 274-311 infra. For articulation of the argument for an even more expanded protection of government employees than that mandated by Roth and Arnett, see Note, The Due Process Rights of Public Employees, 50 N.Y.U.L. REv. 310, 358-64 (1975).

${ }^{239} 367$ U.S. 886, 895 (1961).

240 Id. at 896.

${ }^{241}$ See text accompanying notes 100-119 supra. 
these rather ordinary costs cannot outweigh the constitutional right. . . . Procedural due process is not intended to promote efficiency or accomodate all possible interests: it is intended to protect the particular interests of the person whose possessions [property] are about to be taken. ". . . [T] he Constitution recognizes higher values than speed and efficiency. Indeed, one might fairly say of the Bill of Rights in general, and the Due Process Clause in particular, that they were designed to protect the fragile values of a vulnerable citizenry from the overbearing concern for efficiency and efficacy that may characterize praiseworthy government officials no less, and perhaps more, than mediocre ones."242

Government employees, of course, have the same rights as other members of the general public to challenge governmental regulatory actions. In their capacity as employees, however, they have never been given an equivalent ability to alter government operations to protect their interests. The Supreme Court has recognized consistently that the interests of the government as employer necessitate greater control over employees than the government could justify over the public at large. ${ }^{243}$ The impact of procedural requirements on governmental interests is much more significant in matters of internal administration than in matters of the government's regulatory capacity. Every governmental action-every job assignment, every demand for performance, every distribution of material support-favors some employees over others. Every personnel decision after the initial hiring-whom to assign, promote, transfer, discipline, and discharge_of necessity adversely affects some employees. More is at stake than cost or lost time when formal procedures are estab-

${ }^{242}$ Fuentes v. Shevin, 407 U.S. 67, 90-91 n.22 (1972) (citation omitted) (quoting Stanley v. Illinois, 405 U.S. 645,656 (1972)). The Court has not consistently upheld the Fuentes position that administrative convenience will not affect due process rights in a regulatory context. While some cases have rejected administrative convenience arguments, see Memorial Hosp. v. Maricopa County, 415 U.S. 250, 267-69 (1974); Bell v. Burson, 402 U.S. 535, 540-41 (1971); Goldberg v. Kelly, 397 U.S. 254, 265-66 (1970); of. Sosna v. Iowa, 419 U.S. 393, 406 (1975), other cases have indicated that such an argument is relevant to the due process analysis. See Gagnon v. Scarpelli, 411 U.S. 778, 788 (1973); Richardson v. Perales, 402 U.S. 389, 406 (1971). In its most recent statement on the issue, the Court emphasized that administrative considerations "must be weighed" in formulating constitutional standards, thus undermining the Fuentes position even in a regulatory context. Mathews v. Eldridge, 44 U.S.L.W. 4224, 4233 (U.S. Feb. 24, 1976).

${ }^{243}$ See, e.g., Pickering v. Board of Educ., 391 U.S. 563, 568 (1968). 
lished for these internal matters; the government's very ability to function demands considerable flexibility. As Justice Powell pointed out in Arnett:

[T] he Government, as an employer, must have wide discretion and control over the management of its personnel and internal affairs. This includes the prerogative to remove employees whose conduct hinders efficient operation and to do so with dispatch. Prolonged retention of a disruptive or otherwise unsatisfactory employee can adversely affect discipline and morale in the work place, foster disharmony, and ultimately impair the efficiency of an office or agency. ${ }^{244}$

The Supreme Court recently reaffirmed the distinction between administrative convenience in a regulatory context and the needs of the government to manage its own internal operations in Schlesinger $\%$. Ballard. ${ }^{245}$ The Court there upheld separate promotion rights for men and women in the Navy, distinguishing two prior cases, Reed v. Reed ${ }^{246}$ and Frontiero v. Richardson,${ }^{247}$ which rejected administrative convenience as the sole justification in a regulatory context:

In both Reed and Frontiero the reason asserted to justify the challenged gender-based classifications was administrative convenience, and that alone. Here, on the contrary, the operation of the statutes in question results in a flow in promotions commensurate with the Navy's current needs and serves to motivate qualified commissioned officers to so conduct themselves that they may realistically look forward to higher levels of command. This Court has recognized that "it is the primary business of armies and navies to fight or to be ready to fight wars should the occasion arise.". . . The responsibility for determining how best our Armed Forces shall attend to that business rests with the Congress ... and with the President. ${ }^{248}$

That a governmental function concerns internal administration, of course, does not make it impervious to the requirements

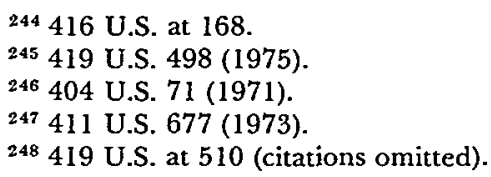


of the Constitution. A further inquiry must be made into whether the governmental action can be subjected to judicial scrutiny to protect individual rights without interfering with appropriate executive functions. Thus the Wieman ${ }^{249}$ and Pickering ${ }^{250}$ Courts recognized that limiting the power of the government to discharge employees for exercising their constitutional rights checked the abuse of executive power without impinging on the essentially executive responsibility of enforcing job-related personnel management and discipline. ${ }^{251}$ A requirement that an allegation of employee misconduct be tried at an evidentiary hearing - if Roth, Sindermann, and Arnett are assumed to mean at least that ${ }^{252}$ - can be viewed as a similarly restrained limitation on executive power. Government cannot justify a discharge for misconduct if the employee "in fact" is innocent of the charge. Determination of guilt or innocence is the classic function of an evidentiary hearing. ${ }^{253}$ Requiring such a hearing need not affect the government's ability to decide what acts of misconduct are grounds for dismissal, assuming no allegation of constitutionally protected activity. Even if there were a requirement that the act of misconduct be shown to be job-related, and thus relevant to the government's interest in internal administration, ${ }^{254}$ such a requirement would not impair the es-

${ }^{249}$ Wieman v. Updegraff, 344 U.S. 183 (1952).

250 Pickering v. Board of Educ., 391 U.S. 563 (1968).

${ }^{251}$ See text accompanying notes 141-57 supra.

${ }^{252}$ Some commentators assume that, after Amett, an evidentiary hearing is always required when the government discharges a civil servant. The only issue, they suggest, is whether that hearing should be before or after the discharge. See, e.g., Comment, supra note 97, at 488-95. If, however, an evidentiary hearing is not required at any time for a dismissal for incompetence, see text accompanying notes 273-87 infra, it nevertheless seems likely that it is required at least for discharges for misconduct. In such cases, an evidentiary hearing would be the functionally appropriate way to determine the existence of the truth of the allegations of misconduct. See Friendly, supra note 175, at 1282-87; text accompanying notes 253-55 infra.

${ }^{253}$ For a discussion of the functions and limitations of evidentiary hearings, see Boyer, Alternatives to Administrative Trial-Type Hearings for Resolving Complex Scientific, Economic, and Social Issues, 71 MICH. L. Rev. 111 (1972); Cramton, A Comment on TrialType Hearings in Nuclear Power Plant Siting, 58 VA. L. Rev. 585 (1972); Davis, The Requirement of a Trial-Type Hearing, 70 HaRv. L. Rev. 193 (1956); Mashaw, The Management Side of Due Process: Some Theoretical and Litigation Notes on the Assurance of Accuracy, Fairness, and Timeliness in the Adjudication of Social Welfare Claims, 59 CORNELL L. REv. 772, 811-24 (1974); Nathanson, Book Review, 70 YALE L.J. 1210 (1961).

${ }^{254}$ A requirement that the reason for discharge be shown to be narrowly tailored to the government's interest in effective work performance would seem necessary in cases where basic freedoms are at stake. See Cleveland Bd. of Educ. v. LaFleur, 414 U.S. 632 (1974); $c f$. Norton v. Macy, 417 F.2d 1161 (D.C. Cir. 1969) (homosexual conduct). See generally Comment, Substantive Due Process: The Extent of Public Employees' Protection from 
sential executive capacity to manage the government. The ability of the government to discharge an employee for non-job-related misconduct is not central to executive power, and a requirement of relevance, as well as the protection of constitutional rights, would be an appropriate method of checking abuse of power.

The governmental function of enforcing a level of job performance, however, is central to government's ability to manage its operations, ${ }^{255}$ and that function is singularly unconducive to judicial scrutiny. Unlike the determination whether an employee is guilty of an act of misconduct, the job of employee evaluation includes the use of a supervisor's good faith subjective judgment. As the Supreme Court emphasized in Keim v. United States, ${ }^{256}$ the essentially subjective nature of an evaluation of incompetence makes the process a peculiarly executive one, so that a judicial attempt to impose constitutional scrutiny of that judgment, absent proof of impermissible bias, would seriously impair the exercise of executive power. ${ }^{257}$

In the government's regulatory capacity, its discretion cannot be based merely on subjective judgment, but must normally be channeled by clear, articulated rules governing its actions. Welfare cannot be terminated, ${ }^{258}$ parole revoked, ${ }^{259}$ or wages subjected to garnishment ${ }^{260}$ without established reasons. One might doubt the constitutionality of a statutory scheme that allowed the government to take such actions without previously articulated governmental rules simply because, for unspecified reasons, the government thought the action wise. Such a statute might be considered unconstitutionally vague or overbroad ${ }^{261}$ or

Arbitrary Dismissal, 122 U. PA. L. Rev. 1647 (1974). The requirement may not be necessary for other discharges. Cf. Thompson v. Gallagher, 489 F.2d 443 (5th Cir. 1973); Beazer v. New York City Transit Auth., 399 F. Supp. 1032 (S.D.N.Y. 1975) (Transit Authority's excluding all participants in methadone maintenance programs held unconstitutional).

${ }^{255}$ See text accompanying notes 98-119 supra.

${ }^{256} 177$ U.S. 290 (1900).

257 See text accompanying notes 129-34 supra.

${ }^{258}$ Goldberg v. Kelly, 397 U.S. 254 (1970).

${ }^{259}$ Morrissey v. Brewer, 408 U.S. 471 (1972); cf. Wolff v. McDonnell, 418 U.S. 539 (1974); Gagnon v. Scarpelli, 411 U.S. 778 (1973).

${ }^{260}$ Sniadach v. Family Fin. Corp., 395 U.S. 337 (1969); $c f$. North Ga. Finishing, Inc. v. Di-Chem, Inc., 419 U.S. 601 (1975); Mitchell v. W.T. Grant Co., 416 U.S. 600 (1974); Fuentes v. Shevin, 407 U.S. 67 (1972).

${ }^{261}$ See generally G. Gunther, Cases and Materials on Constitutional Law 1132-42 (9th ed. 1975); Note, The Void-for-Vagueness Doctrine in the Supreme Court, 109 U. PA. L. Rev. 67 (1960). Precision and tailoring in these contexts serve requirements of notice which need not be as strictly enforced in the employer-employee setting. See 
the procedure adopted might be considered unconstitutional in light of the individual's entitlement to statutory benefits. ${ }^{262}$ Equal protection rights might also be violated. ${ }^{263}$

Yet unarticulated subjective judgment has always been the traditional basis for employee discharges for inadequate job performance, and plainly can continue to be so, even after Roth and Arnett, for those employees without protected property interests in their jobs. Indeed, as indicated above in the discussion of liberty interests, ${ }^{264}$ such an unarticulated judgment may be encouraged by Roth. The courts and the Congress have recognized that, absent any allegation of improper motive, ${ }^{265}$ a supervisor's good-faith judgment is a legitimate-and perhaps inevitable-basis for evaluating employee actions. ${ }^{266}$ Although in some cases, such as routine jobs, a detailed standard of job performance could be articulated, the development of predetermined standards of performance for every employee activity has historically not been required, even in civil service jobs, because of the belief that imposing such an obligation on the government would be so burdensome that retaining an incompetent employee would be preferred to the impossible job of developing the standards. ${ }^{267}$ Such a result has been considered contrary to the nation's interest and to the concept of the

Arnett v. Kennedy, 416 U.S. 134, 158-64 (1974) (plurality opinion). But see id. at 227-31 (Marshall, J., dissenting).

${ }^{262}$ See, e.g., Goldberg v. Kelly, 397 U.S. 254, $261-63$ (1970). See generally Note, Specifying the Procedures Required by Due Process: Toward Limits on the Use of Interest Balancing, 88 HaRv. L. Rev. 1510 (1975).

${ }^{263}$ Denying government benefits to some individuals and awarding those benefits to others might be considered arbitrary or irrational if the classification of the individuals concerned were based on nothing more than the subjective judgment of the government agency administering the program. $C f$. Thompson v. Gallagher, 489 F.2d 443 (5th Cir. 1973) (irrationality of a classification based on honorable-dishonorable discharges).

${ }_{264}$ See text accompanying note 15 supra.

${ }^{265}$ Of course, to the extent that reliance on subjectivity is merely a device to allow discrimination, requiring objective standards for employment actions may be appropriate remedy. See G. Cooper, H. RabB \& H. Rubin, Fair Employment Litigation 176 (1975). It does not follow that subjectivity is inappropriate absent proof of such abuse.

${ }^{266}$ Thus in the recent case of Efthemes v. Commissioners of Civil Serv., 514 F.2d 182 (D.C. Cir. 1975), the court rejected a career civil servant's challenge of his removal for inefficiency on the ground that substantial evidence did not exist to support it: "[T] $]$ here is ample record evidence of his job-related inefficiency; for example, his supervisors described his performance as 'poor,' 'incomplete' and 'inaccurate.' . . There being a rational basis to the Commission's decision, we cannot disturb it." Id. at 184.

${ }^{267}$ See text accompanying notes 13-16 supra. 
merit system itself. Since personnel administration has not developed to the point where the elements of job performance can readily be articulated, ranked, and proven, recognizing the legitimacy of employee evaluations necessitates recognizing, at least in part, reliance on the judgment of supervisory personnel. The nature of such a judgment, one so essentially executive - particularly when it is properly regarded as a central feature of the internal administration of the executive branch of government-thus militates against judicialization of the evaluation process through an expansion of the concept of due process.

\section{The Interest of the Affected Employee}

Cafeteria E Restaurant Workers Local 473 ข. McElroy, ${ }^{268}$ however, requires us to look beyond the nature of the governmental function in determining what due process requires. We must determine also the nature of the "private interest . . . affected by governmental action," 269 and then, presumably, find an appropriate balance between the two. If the inquiry into the private interest is to focus upon the substantiality of the impact on the individual, one must concede quickly that the interest is weighty indeed. Justice Marshall surely had the better of the argument in Arnett when he wrote of the grave consequences to an individual of a dismissal from his job, particularly a dismissal on the basis of poor job performance. ${ }^{270}$ The chances are that a person who is dismissed by the government for incompetence cannot easily find another job. Welfare, despite Justice Powell's suggestion in Arnett, ${ }^{271}$ would often not be an available, let alone an adequate, substitute. The economic and emotional impact of dismissal and consequent unemployment can thus be catastrophic. But once this grave effect on the individual is established, it is uncertain how to weigh its importance against the government's interest. One way is to "balance" the individual's and the government's interests in each case, but such an approach may be inconclusive:

No scale has been calibrated which courts, legislators, and administrators can use to sensitively and predict- 
ably measure either the relative severity of deprivations inflicted upon individuals or the relative importance of governmental interests in summary action. ... [J]udicial reliance upon the interest-balancing doctrine necessarily makes unpredictable what procedures are required by due process in particular cases. ${ }^{272}$

A more feasible balancing approach for protecting both employee and governmental interests is the requirement that the procedure accorded a discharged employee be necessary to guard effectively against improper removal. It should be obvious that the functional utility of a procedure "clearly modifies the weight of the individual's interests in obtaining [it]."273 To justify the requirement of an evidentiary trial in the case of a discharge for incompetence in light of its effect on the government's interest in management of its own employees, one should have to show that it would be not only useful but necessary to protect the employee's interests. ${ }^{274}$ It seems doubtful, however, that an evidentiary hearing is either useful in establishing the existence of competence or necessary to the individual's legitimate need for protection against unfair governmental action. Indeed, other procedures can better ensure fairness in this context. These as-

${ }^{272}$ Note, supra note 262 , at $1519-20$ (footnotes omitted).

${ }^{273}$ Id. 1519. Having argued the utility of a functional approach to due process, id. 1519-23, the Note proceeds to reject the approach as improper on the grounds that it would deny procedural protection to individuals too easily, whenever the general welfare outweighed the need for those protections. Id. 1523-27. The Note proposes, apparently as an addition to a functional analysis, that an individual be entitled to the protection of his procedural rights even if they conflict with the general welfare up to the point where his rights conflict with the rights of other individuals. Under such a test, Arnett becomes an easy case: since no other specific individual's rights would be infringed by the employee's right to a hearing, the employee is entitled to the hearing. Id. 1525-27, 1534-35. The difficulty with the Note's approach to Arnett is that it assumes the existence of the right to a hearing, and therefore protects that right against a denial on utilitarian grounds, when the true question in the Arnett type of case is whether the employee has a right at all. Had the Note subjected the hearing envisioned in Arnett to a functional analysis, I submit that, at least in cases concerning competence, it would have found no right to protect. See text accompanying notes 274-87 infra. In this Article, I do not deal with the additional question concerning the circumstances under which the government still can deny a hearing once functional utility is demonstrated. I argue simply that the requisite functional utility cannot be shown to justify an evidentiary hearing in case of discharge for incompetence.

${ }^{274} \mathrm{Cf}$. Friendly, supra note 175, at 1278. In Mathews v. Eldridge, 44 U.S.L.W. 4224 (U.S. Feb. 24, 1976), the Court held that a recipient was not entitled to an evidentiary hearing prior to termination of Social Security disability benefits, distinguishing Goldberg v. Kelly, 397 U.S. 254 (1970) not only because the impact on the recipient was less severe but also because the potential value to the recipient of an evidentiary hearing was substantially less than in Goldberg. Id. at 4232. 
sertions can best be understood by reference to an analagous situation, that of students suspended or dismissed from school.

Last Term, in Goss v. Lopez, ${ }^{275}$ the Supreme Court held that some constitutional procedure is necessary before a student can be suspended for misconduct. In the case of a suspension for ten days or less, the Court held that a student must be given notice of and a right to reply to the charges against him, but suggested that longer suspensions or expulsions might require more formal procedures. Although conscious of the effect formal procedures might have on the educational process, the Court implied that the necessity of formality turned on the extent of harm imposed on the students. ${ }^{276}$ Yet if a student were discharged not for misconduct but for failing his examinations, one would doubt that the Court would require a judicial trial to determine if he "in fact" failed his examinations, even if the penalty, expulsion, were greater than the penalty incurred in Goss itself. Basic to the holding in Goss is the belief that the determination whether the student is guilty of misconduct is a question of fact, and that the establishment of certain procedures is both useful to ascertain the correctness of that fact and necessary to protect the student's interest. In contrast, a judicial trial to determine whether a student failed his examinations would often not be useful in determining the truth of alleged facts, because the existence of failure is often not an ascertainable issue of fact. The judgment of the instructor may itself be the fundamental definition of the concept of "failing." A judicial trial on the issue of failure implies quantification of the ingredients of failure, so that the existence of these ingredients can be proven. But if such a quantification is not a usual or necessary part of the judgment of failure (as in complex examinations), the evidentiary trial would either have to require the invention of such a quantification or simply ratify the good faith judgment of the instructor. Because the courts could not adequately review the ultimate academic judgment even if quantification were required, an evidentiary trial would be without its traditional truth-finding utility.

In Gaspar v. Bruton, ${ }^{277}$ a student practical nurse who had successfully completed her examinations challenged her dismis-

275419 U.S. 565 (1975).

${ }^{276} I d$. at 584 .

${ }^{277} 513$ F.2d 843 (10th Cir. 1975). 
sal for unsatisfactory performance in clincial courses. She claimed that the Constitution required that she be given a full evidentiary hearing prior to her dismissal to determine if in fact she had performed incompetently in the clinical program. The Board had already provided her with a full evidentiary trial after her dismissal, but the Tenth Circuit said that even that was more process than had to be accorded in the case of academic suspension or termination.

The Courts are not equipped to review academic records based upon academic standards within the particular knowledge, experience and expertise of academicians. Thus, when presented with a challenge that the school authorities suspended or dismissed a student for failure re academic standards, the court may grant relief, as a practical matter, only in those cases where the student presents positive evidence of ill will or bad motive. ${ }^{278}$

Similarly, in Whitfield v. Illinois Board of Law Examiners, ${ }^{279}$ the plaintiff, who had failed the bar examination five times, claimed, among other things, the right under procedural due process to see his examination papers and compare them with those of successful applicants to determine if he "in fact" had failed his examinations. The court rejected the claim, saying that a comparison would be meaningless unless plaintiff were also able to confront the bar examiners and obtain from them explanations of the grades. The court said that such a procedure would place an intolerable burden on bar examiners. ${ }^{280}$

Of course, sometimes the issue of failure includes questions of fact-whether the minimum number of correct answers were given in an objective examination-but a judicial trial in such a case is unnecessary to protect the student's basic demand for fairness. Unlike the situation in which misconduct must be established, there is little room for doubt about what the facts are. Ascertaining the facts in such a case is so simple that, absent an allegation of bias or impermissible motive, an adequate check on

278 Id. at 851 .

279504 F.2d 474 (7th Cir. 1974).

${ }^{280}$ Id. at 478. See Tyler v. Vickery, 517 F.2d 1089, 1103-05 (5th Cir. 1975), in which the court rejected an argument that the due process clause required a hearing to determine whether the plaintiff in fact failed the Georgia bar examination, holding instead that reexamination would satisfy constitutional requirements. 
accuracy would be another look at the examination paper-a supervisor's look would be the most that might be required. A requirement of an evidentiary trial, burdensome without utility in cases of subjective judgment, is burdensome without necessity in cases in which the contested factual issues can be easily and objectively resolved.

A discharge for inefficiency in the employment setting is analagous to expulsion for academic failure in the education setting, and ought similarly to be distinguished from cases of misconduct. Although in a case of discharge for misconduct the employer is in no better position to decide if the employee is in fact "guilty" of the alleged act of misconduct than an impartial third party would be, the day-to-day supervisor's poor rating of the employee's performance is itself an important determinant of the lack of competence. ${ }^{281}$ The Third Circuit in In-Cho Chung v. Park ${ }^{282}$ recently recognized that this necessary subjectivity undermines the usefulness of an evidentiary hearing as a method of establishing the correctness of factfinding. In In-Cho Chung a biology professor challenged a state college's refusal to renew his contract on the ground of poor job performance. The court said that in this type of case, "[d]ue process should not be employed to insure that this exercise of discretion is 'wise' but only that it is not unreasonable, arbitrary or capricious." 283

Here we are not dealing with a decision whether Dr. Chung satisfied a specific set of statutory or administrative conditions which would have entitled him to continuing employment. Rather, we are concerned with an exercise of discretion by the college administration as to whether Dr. Chung was competent to perform the duties of a professor. By its nature this type of decision cannot be adjudged as correct or erroneous, but only as reasonable or unreasonable. ${ }^{284}$

Of course, it could be argued that an evidentiary trial would be useful in establishing the issue of competency if formulated as an issue of fact. The object of such a trial would be simply to determine whether the employee had done what he was charged with doing. But establishing the accuracy of facts is not really

\footnotetext{
281 See text accompanying notes 255-67 supra.

${ }^{282} 514$ F.2d 382 (3d Cir.), cert. denied, 96 S. Ct. 364 (1975).

${ }^{283} \mathrm{Id}$. at 387 .

${ }^{284}$ Id. at 387 n.8.
} 
how the process of employee evaluations works. Indeed, when factfinding becomes the focus, the true issues in establishing fairness in employee evaluations are often lost in the process of resolving largely irrelevant factual disputes. Foster $v$. Laroque ${ }^{285}$ sharply illustrates this problem. In that case, the plaintiff was removed as a clerk-stenographer on the basis of her inefficient performance of duties. Her specific instances of inefficiency were stamping an incorrect date on incoming mail, failing to type a line of a report, using a wrongly numbered form for a travel request, and making a typographical error in a certain document. Although the plaintiff conceded that these incidents had occurred as alleged, ${ }^{286}$ she sought review of her dismissal through the federal courts; the Supreme Court denied certiorari over six years after her discharge. Her basic challenge seemed to be that the allegations were trivial and insufficient to justify the discharge. The courts refused to evaluate whether the charges were sufficiently serious for an employer to base a dismissal on them.

Yet if all an employer must do to discharge an employee for incompetence is compile and prove such a list of mistakes, then any employee can be discharged. Everyone makes mistakes. Unless the court establishes standards of incompetence, an evidentiary trial procedure designed to establish the facts on which the charged incompetence is based seems pointless at both the judicial and administrative levels. But a judicial definition of incompetence would deny an administrator the ability to decide the level of job performance that he, in good faith, deems necessary for his employees. This would be a significant invasion of executive power. Although it might well be within the judicial role to require that acts of misconduct be relevant to job performance before they can be the basis of discharge, ${ }^{287}$ it would be quite another matter for the judiciary to decide, absent an allegation of bad faith or impermissible bias, that deficiencies clearly relevant to job performance are not "enough" for discharge. Before such an invasion of executive power is required in the name of due process, it should at least be justified by a showing that judicialization by means of an evidentiary trial requirement is the

285246 F. Supp. 911 (E.D. La. 1965), aff'd sub nom. Foster v. United States Civil Serv. Comm'rs, 369 F.2d 399 (5th Cir. 1966), cert. denied, 386 U.S. 1038 (1967). See Blunt v. Hanon County School Bd., 515 F.2d 951 (5th Cir. 1975).

286246 F. Supp. at 914 n.3.

${ }^{287}$ See note 254 supra \& accompanying text. 
only way to ensure fairness when an employee is discharged for incompetence. But an evidentiary trial is not in fact necessary to establish fairness in the employee evaluation process.

\section{Fairness in Employee Discharges}

Fairness in cases of discharge for misconduct depends solely on factfinding, assuming no allegations that constitutionally protected rights are involved or that the misconduct is not jobrelated. Resolution by evidentiary trial that the act of misconduct was committed is dispositive of the issue whether the discharge was fair. The key to fairness in the determination of competence, however, is not the resolution of purely factual issues but the process used by a supervisor in evaluating that competence. An employee is more likely to complain "I didn't know I had to do (couldn't do) that" or "other guys get away without (with) doing it" than he is to question the factual accuracy of the charge against him. Factual disputes as to the quality or quantity of work are usually resolvable at the time the issue arises; complaints about the process used to evaluate whether the quality or quantity of work amounted to incompetence cannot be so resolved.

To be fair, an evaluation process must provide adequate notice to the employee of what is expected of him and adequate warning about his deficiencies in fulfilling those expectations in advance of discipline or discharge. An employee must have the opportunity to perform as expected and be given the chance to appreciate the consequences of failure. Thus the fairness of discharging a mail carrier for not delivering mail might turn on whether it was his first or hundredth day on the job, whether he was told what he had to do, and whether he was warned about the consequences of failure. A finding that he "did it" does not ensure fairness. ${ }^{288}$ Moreover, if an evidentiary trial is necessary, the employer is faced with taking an action immediately after the occurrence of some improper behavior or accumulating offenses until action is taken. Some have criticized the accumulation of relatively minor offenses as being unfair. ${ }^{289}$ Yet surely bringing a

${ }^{288}$ Cf. United States Postal Serv. \& Nat'l Ass'n of Letter Carriers, Discharge of Donald Orloski, Grievance No. N-E-83, BNA Gov'T EmPloyee ReL. ReP. No. 469, at 209 (1972).

289 "[Discipline] cannot reasonably be read to permit a series of minor offenses to pass relatively unnoticed, so as to accumulate a large number of them to support a discharge. Discipline hardly can be effective and fair when it is not administered promptly, with each offense dealt with on its own facts." Id. at 213; $c f$. TASK ForCE ON 
disciplinary action at the time of the first infraction would also be unfair. Some system of regular communication seems to be the essence of fairness in cases of evaluation of job performance.

Another problem of fairness in personnel evaluation stems from a claim that the supervisor's evaluation was based on personal bias, since the employer-employee relationship is nothing if it is not a personal, sometimes tormented, ${ }^{290}$ relationship. Indeed, most personnel removal actions involve the personalities of both the supervisor and the person evaluated, and indeed may be as much a reflection of poor supervision and guidance as of poor employee work performance. Fairness prior to discharge would therefore require that another supervisor inquire into the work situation to ensure that the discharge was justifiable. Such an inquiry cannot be made simply by litigating the facts underlying the charge of incompetence. The additional inquiry must be broader, and it of necessity involves the responsibility of management to evaluate supervisory personnel. If the bias alleged is personal, or if the employee seeks to shift the fault to the supervisor, that kind of complex personnel issue can be resolved properly only by other people in the organization in daily contact with the employment situation; it is not the type of situation in which fairness can be determined by the judicial model of a trial.

Only if the allegation of bias is one that might be institutionalized-such as racial, religious, or political prejudice or the curtailment of the exercise of constitutionally protected liberties-would it be necessary for an impartial third party to make the evaluation. Wieman and cases following it suggest no other need to restrict the government's ability to evaluate its own performance. ${ }^{291}$ There is, of course, a danger that the higher-up might automatically side with the supervisor, but the current judicialization does not solve that kind of "tilt" in the system. $^{292}$ Only fairness in the internal employee evaluation pro-

Personnel and Civil Service of the Commission on Organization of the Executive Branch of Government, Personnel and Civil Service 96 (1955).

${ }^{290}$ For one author's view of this relationship, see J. Helter, Something Happened (1974).

${ }^{291}$ See text accompanying notes 141-63 supra; cf. Friendly, supra note 175 , at 1279-80. When racial bias is a potential factor in the discharge, courts may be reluctant to uphold the discharge even when substantial evidence of incompetence exists. See, e.g., United States v. Coffeeville Consol. School Dist., 513 F.2d 244 (5th Cir. 1975).

${ }^{292}$ For a general discussion of methods used to by-pass the judicial mechanism, see R. VAUGHN, supra note 16, at 13-27. The author sees the expansion of hearing rights as a way to protect employees from arbitrary action. See id. 169-76. 
cess can significantly protect the employee from his supervisor's personal animosity.

Given the central role of the evaluation process in the determination of the fairness of the judgment of incompetence, the appropriate role of the courts-and the concept of due process-in reviewing employee discharges for inadequate job performance is a review of the fairness in that process. Such a review of the process is all that is necessary, or even useful, to establish fairness in such cases. The close relationship between fairness and the internal evaluation process is consistent with modern theories of personnel management, which suggest that requiring a trial-type inquiry into facts underlying a supervisor's decision to discharge impairs, rather than promotes, both fairness and effectiveness in personnel management.

The classic exposition of current approaches to employee evaluation is Douglas McGregor's comparison of two concepts of personnel management, which he labels Theory $\mathrm{X}$ and Theory $\mathrm{Y}^{293}$ Theory $\mathrm{X}$, the traditional approach, is based on the assumption that individuals avoid work if they can, and that to make them work they need to be "coerced, controlled, directed, [and] threatened with punishment to get them to put forth adequate effort toward the achievement of organizational objectives."294 Theory $\mathrm{X}$ is management by superior force. In contrast, Theory $\mathrm{Y}$ emphasizes creating work incentives through participatory leadership, with the key to personnel management being the creation of a job environment encouraging an employee's commitment to his work. According to Theory $Y$, employees "will exercise self-direction and self-control in the service of objectives to which [they are] committed."295 The manager must work jointly with his employees to set goals for the job to be done and methods to evaluate success or failure. The object is management by objective rather than management by control. There has been an increasing shift to the use of Theory $\mathrm{Y}$ in private business. ${ }^{296}$

${ }^{293}$ D. MCGregor, The Human Side of Enterprise $33-57$ (1960). See also D. MCGregor, Leadership and Motivation (1966); McGregor, An Uneasy Look at Performance Appraisal, 50 Harv. Bus. Rev., Sept.-Oct. 1972, at 133.

${ }^{294}$ D. MCGregor, The Human Side of ENTERPrise, supra note 293, at 34.

295 Id. 47.

${ }^{296}$ See, e.g., Allen, $M$ for Management: Theory $Y$ Updated, 52 Personnel J. 1061 (1973); Greiner, What Managers Think of Participative Leadership, 51 HARv. Bus. Rev., Mar.-Apr. 1973, at 111; White \& Barnes, Power Networks in the Appraisal Process, 49 HaRv. Bus. Rev., May-June 1971, at 101, 108; $f$. Morse \& Lorsch, Beyond Theory $Y, 48$ 
Current governmental personnel evaluation procedures, encouraged by the judicialization of the removal process, are firmly based on Theory X. The system of regular written evaluations of the inferior by the superior, with discipline based on the concept of building a record against the employee in the preparation for trial, necessitates an adversary employer-employee relationship. McGregor claims that this Theory $\mathrm{X}$ approach is unfair both to the management and the employee since it will not only fail to improve work performance, but will also fail to produce effective evaluation of the employee. Because managers are "uncomfortable when they are put in the position of "playing God" "297 with people's lives, the task of evaluation is often left undone. Employees are not encouraged to work, but neither are they fairly evaluated. The result is that employees are often not treated in accordance with their performance, whether favorably or unfavorably. Reliance on Theory X, together with the difficulties of judicialization itself, may help explain why few people are now fired from government for incompetence. ${ }^{298}$

If government were to adopt Theory $\mathrm{Y}$ as its personnel approach, the combat relationship inherent in the judicial model would be eliminated. The employer would no longer be expected to keep a record of his employee's faults; the employee evaluation would be by regular communication between the parties. This does not mean that there would be no evaluation of the employee's work performance. If the employee failed to perform when given not only notice of what was reasonably expected of him but also the ability to participate in formulating those expectations, he would be discharged.299 But if that process was fair-if the employee was given a fair chance to do the job-the employee should not then be allowed to litigate either administratively or judicially whether his discharge was "right." Theory $\mathrm{Y}$ could not work if an adversary relationship always lurked in the background. The key to the success of Theory $\mathrm{Y}$ is the fairness in the employer's relationship with the employee. A government experiment with a Theory $\mathrm{Y}$ evaluation process,

Harv. Bus. Rev., May-June 1970, at 61; Thompson \& Dalton, Performance Appraisal: Managers Beware, 48 HaRv. Bus. REv., Jan.-Feb. 1970, at 149.

${ }_{297}$ See McGregor, An Uneasy Look at Performance Appraisal, supra note 293, at 134.

${ }^{298}$ See note 13 supra \& accompanying text.

${ }^{299} \mathrm{McGregor}$ recognizes that reliance on managerial judgment is still necessary under Theory Y. See D. MCGREgor, Leadership and Motivation, supra note 293, at 188, 195-96. 
without a trial as to the underlying facts, ought not to be constitutionally impermissible.

The second Hoover Commission confirmed McGregor's analysis of the defects of Theory $\mathrm{X}$ when it found that requiring a judicial trial for incompetence has both hampered government management and necessitated a process that is detrimental to the employee.

A judicial proceeding such as an appeal under Section 14 [of the Veterans Preference Act] leads to the worst kind of supervisor-employee relations because it requires the building of a written record and the accumulation of formal evidence sufficient to stand up as a support for the supervisor's action. It relieves the employee of any necessity for demonstrating his competence and usefulness to his department, and in effect, guarantees him a job unless his supervisor can prove in a formal proceeding that he is incompetent. This leads to working situations which are intolerable. If the supervisor acts on his best judgment, he normally disciplines or separates an employee as soon as the misconduct occurs or the incompetence is evident. But, if he does so, he may be unable to substantiate his action judicially because he has not waited to accumulate documentary evidence. In other words, there now tends to be a fairly long series of events leading up to a final action by a supervisor. The requirements of Section 14 emphasize the need to build a record to "get" someone rather than encourage good employer-employee relationships. . . . This sort of struggle does not help the organization, the employee, or the supervisor. ${ }^{300}$

If "due process" requirements were interpreted to emphasize procedural fairness in the internal employment process rather than the existence of facts underlying competence, the Constitution might also begin to protect the great bulk of employees who lose their jobs not after a trial but after a closed door, heart-to-heart talk with the boss. ${ }^{301}$ It might also protect

300 Task Force on Personnel and Civil Service, supra note 289, at 96.

${ }^{301}$ See R. VAUGHN, supra note 16, at 15-16. Plaintiffs who resign now have the difficult burden of proving that their resignations were involuntary. Without such a showing, there is no "taking" of a property interest in violation of Roth and Arnett. 
some of those who resign because they are passed over for promotion or given undesirable job assignments. As any employer will tell you, a formal action need not be brought to discharge an employee. Work can be made unpleasant enough to produce that effect without bringing an action. ${ }^{302}$ Yet the solution to these informal removals-so full of the dangers of abuseought not to be the requirement of an evidentiary trial on the exercise of the management judgment about promotion or work assignment. A requirement of some sort of internal procedure to ensure that bias or irrelevant motives are not the basis for the personnel action would be more appropriate. If a fair procedure was followed, the courts should not look into whether the promotion or work assignment was "right." If no procedures were followed, the courts should not impose a procedure based on a judicial model, but could require that the executive design one of its own choosing.

An example of an effort at establishing fairness in employee promotion that has attracted much attention is the development of assessment centers, ${ }^{303}$ in which company managers spend a number of days independently assessing candidates for promotion. After a series of tests, interviews, and other exercises, the managers evaluate the contestants in light of their capacity for advancement. One could argue that such a process is unfair unless the employee can have a trial-type hearing to determine whether he "in fact" failed to meet the specified level of performance. Yet the assessment center seems a fair way of evaluation in that it seeks to minimize the likelihood of any personal bias. The government's adoption of an assessment center approach for civil servants entitled to promotion should not be unconstitutional. A trial-type hearing should not be necessary simply because the penalty of not being promoted seems grave enough to require one. Rather, the issue should be whether the methods adopted by the government give the competing employees a fair chance of advancement.

It might be objected that the concept of due process advanced here simply is not enough to protect a civil servant. If the

Christie v. United States, 518 F.2d 584, $588-89$ (Ct. Cl. 1975); Gratehouse v. United States, 512 F.2d 1104 (Ct. Cl. 1975).

${ }^{302}$ R. VAUGHN, supra note 16 , at $19-25$.

${ }^{303}$ See, e.g., Byham, Assessment Centers for Spotting Future Managers, 48 Harv. Bus. Rev., July-Aug. 1970, at 150; Wilson \& Tatge, Assessment Centers-Further Assessment Needed? 52 Personnel J. 172 (1973). 
employer need not "prove" incompetence at a judicial trial, it might appear that all employees become subject to termination at executive will. Even if the real reason for discharge is irrelevant misconduct, bias, or politics, a mere supervisory judgment of poor performance, reviewed by a friendly higher-up in the agency, could serve to discharge anyone successfully and without controversy. This would seem particularly unfair in the civil service, where everyone has proved a level of competence by being appointed through a merit system in the first place. An evidentiary trial might seem necessary to prevent a recurrence of the spoils system or, perhaps worse, a government by arbitrary power.

Such an argument is based on a series of misapprehensions. The result of a reformation of the concept of due process as suggested here merely shifts the burden to the employee to prove that his discharge is based on political or otherwise inappropriate motives. This is where the burden normally rests when a plaintiff alleges denial of procedural due process. ${ }^{304}$ Once there is some evidence of impermissible motive, an evidentiary trial on the existence of such a motive is appropriate. But the government will retain the power to discharge the individual without trial if such a motive is not proven. No doubt placing the burden of proof on the employee and strengthing the reliance on executive discretion increases the power of the executive over its employees. Such a shift of power is the purpose of the change in procedures. If that power is exercised in accordance with fair personnel procedures, however, the Constitution ought not to prohibit such power in the relationship between the government and its civil service.

Nor can it be maintained that civil servants are entitled to greater protection of job security because they have proven their competence merely by being hired in the first place. The assumption that the merit system ensures that appointments are based on the merits of the candidates has lost much of its force. ${ }^{305}$ In the early days of civil service reform, the Service was

${ }^{304}$ The plaintiff has the burden of proving that his liberty or property has been denied and that he is therefore "entitled" to certain procedures. Once a hearing is granted he must then prove that the basis for the adverse action was in fact an infringement of his liberty or was otherwise unjustified. See Perry v. Sindermann, 408 U.S. 593, 598 (1972).

${ }^{305}$ See, e.g., Peirce, supra note 12; Savas \& Ginsburg, The Civil Service: A Meritless System?, 32 PUв. INTEREST 70, 75-77 (1973); Laing, supra note 16. 
confident that it could develop an examination to select the most qualified candidates for any type of job. ${ }^{306}$ Today, most major civil service examinations, federal and state, including the Federal Service Entrance Examination, are under attack on the ground that there is no validated relationship between passing the test and good job performance. ${ }^{307}$ Some cases have gone so far as to indicate that the distinction between those who pass and those who fail the test is simply arbitrary. ${ }^{308}$ Moreover, the use of even a validated written examination is unlikely to select the best qualified candidates, since test scores can show only whether the applicant could perform a particular job, not whether he has performed in prior jobs or will perform in the job at hand. Indeed, the reliance of state and local civil service systems on promotional examinations rather than on performance evaluation as the criterion for advancement has been criticized as a major factor in undermining the incentive for good job performance in the government service. ${ }^{309}$ Finally, even if reliance on a written examination were proper, the list of those eligible to take the examinations is often compiled so far in advance that many qualified people will already have taken other work prior to the administration of the examination. And other factors, veterans' preference being the most common, ${ }^{\mathbf{3 1 0}}$ may even preclude hiring the person with the highest score on the list of successful examinees. Of course, the process may produce the best people, but not necessarily. Once the employees are hired, the extensive use of a probationary period before permanent status is awarded is unlikely to weed out all those not fit to continue. A decision to discharge a provisional appointee often means a long delay before the agency can find a replacement, if indeed a replacement can be made. Supervisors are reluctant to trade an existing em-

306 VAN RIPER, supra note 29, at 194.

${ }^{307}$ E.g., Douglas v. Hampton, 512 F.2d 976 (D.C. Cir. 1975) (Federal Service Entrance Examination); Davis v. Washington, 512 F.2d 956 (D.C. Cir.), cert. granted, $96 \mathrm{~S}$. Ct. 33 (1975); NAACP v. Beecher, 504 F.2d 1017 (1st Cir. 1974), cert. denied, 421 U.S. 910 (1975); Bridgeport Guardians v. Civil Service Comm'n, 482 F.2d 1333 (2d Cir. 1973), cert. denied, 421 U.S. 991 (1975); Jones v. Human Resources Adm'n, 391 F. Supp. 1064 (S.D.N.Y. 1975); $c f$. Griggs v. Duke Power Co., 401 U.S. 424 (1971).

${ }^{308}$ Chance v. Board of Examiners, 458 F.2d 1167, 1177 (2d Cir. 1972).

${ }^{309}$ See Savas \& Ginsburg, supra note 305, at 77-79.

${ }^{310}$ Veterans were given preference in the federal service on an informal basis until 1865 , when the first of a series of statutory preferences was enacted. D. ROSENBLOOM, supra note 26, at 133-34. See generally United States Civil Service Comm'n, Veterans Preference in Federal Employment (1957). 
ployee of any quality for the mere possibility that the system may produce someone better.

It might be objected that requiring some constitutionally prescribed minimum procedure in internal employee evaluation is too great, rather than too narrow, a limitation on executive personnel management. If the courts are going to review such a purely executive function as the executive's personnel process, then the unwarranted judicial invasion of the executive's power over its employees, objected to in the history of the federal cases, will still occur. But as long as Arnett's holding that civil servants have a property interest in their jobs remains valid, ${ }^{311}$ some judicial incursion into the personnel process is unavoidable. Moreover, the limitation on the executive to use a fair procedure of its own design is considerably less an invasion of the executive function than the imposition of a judicially designed procedure modeled on an evidentiary trial. Some sort of review of executive procedures in light of the current standards of fairness is a traditional judicial function. As long as the review does not freeze the executive into a particular conception of a fair procedure, the imposition of the concept of fairness in the management of government is not unjustifiable.

\section{Requirements for the Protection of "Liberty"}

If the civil servants who have a "property" interest in their jobs cannot demand an evidentiary trial prior to discharge for incompetence, they, and government employees without property interests, ought not to be able to demand such a trial because of a "liberty" interest in their reputations. The Roth definition of liberty ${ }^{312}$ need not require a judicial trial in the case of every discharge for incompetence. Some courts have held that mere criticism of work performance, not being a charge of immorality or infamy, is insufficient to constitute a deprivation of liberty interests. ${ }^{313}$ Others have assumed, however, that the protection of liberty now prevents any impairment of reputation by government without judicial trial. In dealing with this broader view, the Fifth Circuit has held that the liberty interest can be protected if the grounds for discharge are not made public, even if they exist in a confidential file describing the personnel

${ }^{311}$ See text accompanying note 193 supra.

${ }^{312}$ See text accompanying note 214 supra.

${ }^{313}$ Calo v. Paine, 385 F. Supp. 1198, $1205-08$ (D. Conn. 1974); Berry v. Hamblin, 356 F. Supp. 306 (M.D. Pa. 1973). 
action. ${ }^{314}$ Such a notion would allow the government to discharge individuals without an evidentiary trial for stated reasons, even for cause, if the government specifies the basis for discharge only to the individual and not to future employers. It may be objected that if the employee knows the reason, he will have to tell a future employer when asked, and thus ought to be able to challenge the accuracy of the allegation. ${ }^{315}$ Such reasoning, if accepted, would require a judicial trial in every case. Perhaps the government can protect the individual by specifically forbidding inquiry into the government's ground for discharge, a procedure that would protect the public sector's flexibility at the expense of prohibiting the private sector from gaining relevant knowledge of its employees..$^{316}$ Even if that were done, one still would be left with the difficulty that any such employee, merely because of a discharge for unexplained reasons, would find it difficult to find a future job. Yet Roth has already indicated that such a difficulty is not itself a violation of the liberty interest protected by the Constitution. ${ }^{317}$

\section{Conclusion}

I have argued in this Article that Roth, Sindermann, and $A r$ nett need not be interpreted as mandating what most of the history of government employee relations and of the federal removal cases has sought to avoid: a required evidentiary trial prior to a discharge for incompetence. Instead, if the executive establishes safeguards regulating the evaluation process itself, these safeguards should be sufficient to satisfy the modern concept of procedural due process. One cannot be sure that the approach to procedural safeguards outlined here will protect individuals adequately from arbitrary government power. Perhaps President Kennedy's 1962 extension of the notion of an

${ }^{314}$ Ortwein v. Mackey, 511 F.2d 696 (5th Cir. 1975); $c f$. Sims v. Fox, 505 F.2d 857, 863 (5th Cir. 1974) (en banc), cert. denied, 421 U.S. 1011 (1975). Cf. Greenhill v. Bailey, 519 F.2d 5 (8th Cir. 1975), in which the court, having held that the discharge of a medical student for lack of intellectual ability violated the student's liberty interest because the information was communicated outside the school, limited the due process procedure to notice and a right to reply, and rejected the necessity of a trial-type hearing.

${ }^{315}$ Sims v. Fox, 505 F.2d 857, 865 (5th Cir. 1974) (en banc) (Tuttle, J., dissenting), cert. denied, 421 U.S. 1011 (1975).

${ }^{316}$ See Casey v. Roudebust, 395 F. Supp. 60, 63 (D. Md. 1975) requiring defendant either to provide a hearing or to remove from his files "all material relating to the reason for the termination...."

${ }^{317}$ Board of Regents v. Roth, 408 U.S. 564, 574 n.13 (1972). 
outside review by evidentiary trial ${ }^{318}$ is a wise and necessary step toward the protection of the individual. But in this area of uncertainty, an area critical to the power of the executive to control the government itself, one should not transform recent wisdom into constitutional mandate. Flexibility to fix the balance between the needs of executive authority and the protection of individual rights ought to be preserved unless there is only one way to ensure basic fairness. The judicialization of the employment process is too new to become the constitutional definition of fairness, especially in light of weaknesses already apparent. Government employment may be neither a privilege nor a right, but it is a function central to the future of the country. The formulation of the proper protection of that function from executive power has been a subject debated throughout the nation's history. The difficult process of achieving the elusive balance of job security and proper administration must not be denied continuing development through the political process.

${ }^{318}$ See text accompanying notes 93-96 supra. 